\title{
Synthesis and Gastrointestinal Prokinetic Activity of Novel Benzamide Derivatives with Amphoteric Side Chains
}

\author{
Jun SAKaguchi, ${ }^{* a}$ Nobuhiko Iwasaki, ${ }^{a}$ Yuji Iwanaga, ${ }^{a}$ Takaharu SAIto, ${ }^{a}$ Eiji Takahara, ${ }^{a}$ \\ Hideo Kato, ${ }^{a}$ and Miyoji HaNaOKA ${ }^{b}$ \\ Research Division, Hokuriku Seiyaku Co., Ltd., ${ }^{a}$ Inokuchi 37-1-1, Katsuyama, Fukui 911-8555, Japan and Faculty of \\ Pharmaceutical Sciences, Kanazawa University, ${ }^{b}$ Takara-machi 13-1, Kanzazawa, Ishikawa 920-0934, Japan. \\ Received October 19, 2000; accepted December 12, 2000
}

\begin{abstract}
Novel benzamide derivatives $(19-24,32 a-c, 43 d-f)$, each possessing a cycloaminoalkanecarboxylic acid side chain, were synthesized and their gastrointestinal prokinetic and dopamine $D_{2}$ receptor antagonist activities were evaluated. 4-[(4-Amino-5-chloro-2-methoxybenzoyl)amino]-1-piperidineacetic acid (19) exhibited the most potent gastro- and colon-prokinetic activities, through intravenous administration to conscious dogs, and also showed the reduced dopamine $D_{2}$ receptor antagonistic activity. However, 19 showed only weak gastrointestinal prokinetic activity after oral administration. Several ester prodrugs $(44-62)$ of 19 were tested for pharmacological activities as well as physicochemical and metabolic stability; the butyl ester (46) was consequently selected as a promising gastrointestinal prokinetic agent with reduced side effects.
\end{abstract}

Key words gastroprokinetic activity; colon-prokinetic activity; 5-HT 4 agonist; 4-[(4-amino-5-chloro-2-methoxybenzoyl)amino)]-1piperidineacetic acid

Metoclopramide (1a), possessing a dopamine $\mathrm{D}_{2}$ receptor antagonist and weak serotonin $5-\mathrm{HT}_{4}$ receptor agonist activities, $\left.{ }^{1 a}\right)$ is used clinically as a gastrointestinal prokinetic and an antiemetic agent. ${ }^{1 b)}$ However, its clinical application is limited due to its side effects, such as extrapyramidal syndrome, parkinsonism and elevated serum prolactin levels, caused by blockage of the dopamine $\mathrm{D}_{2}$ receptor.

We previously reported that the introduction of a methylenephenoxy group between the benzamide moiety and the terminal aminoalkyl groups of 1a led to the discovery of itopride (2), with an appropriate dopamine $\mathrm{D}_{2}$ receptor antagonist activity and a distinctive acetylcholine esterase inhibitory activity. ${ }^{2)}$ On the other hand, we suggested that amphoteric-ionization would be a useful approach to discovering a new drug, and actually succeeded in finding selective histamine $\mathrm{H}_{1}$ antagonists by applying this method to classical antihistaminics. ${ }^{3)}$ We initially applied the amphoteric-ionization to 1a in order to find a new type of gastrointestinal prokinetic agent. Although we preliminarily synthesized an amphoteric-ionized compound (3) by the introduction of an alkanecarboxylic acid moiety onto the terminal nitrogen atom of 1a, it had no significant gastrointestinal prokinetic activity. Cisapride (1b), ${ }^{4)}$ which has a conformationally restricted amino moiety in comparison with $\mathbf{1 a}$, has been found to show more potent gastrointestinal prokinetic activity than 1a. We therefore expected that some kind of conformational restriction of 3 would lead to an increased gastrointestinal prokinetic activity, and designed a series of [[(4-amino-5chloro-2-methoxybenzoyl)amino]cycloamino]alkanecarboxylic acid derivatives (4).

In this paper, we describe the synthesis and gastrointestinal prokinetic activity of a series of [[(4-amino-5-chloro-2methoxybenzoyl)amino]cycloamino]alkanecarboxylic acids (4). We also discuss conformational effects on gastrointestinal prokinetic activity and the evaluation of ester prodrugs of 4-[(4-amino-5-chloro-2-methoxybenzoyl)amino]-1piperidineacetic acid (19), which exhibited the most excellent gastrointestinal prokinetic activity.

Chemistry New amphoteric compounds (19-24, 32ac, $38,43 \mathrm{~d}-\mathrm{f})$ and prodrugs $(44-60)$ of compound 19 were synthesized as shown in Charts $2-6$.

As shown in Chart 2, benzamides (19-24) with 1-

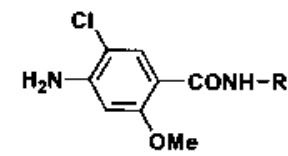

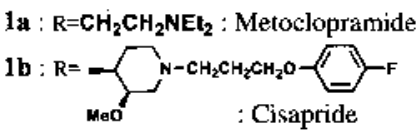

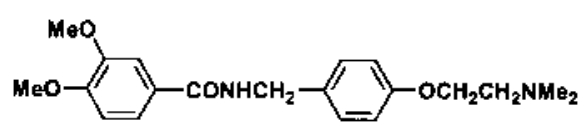

2 :Itopride<smiles>CCN(CCNCCC(=O)O)CCNC(=O)c1cc(Cl)c(N)cc1OC</smiles>

3

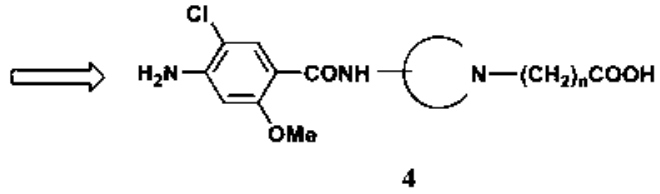

Chart 1 
Method A
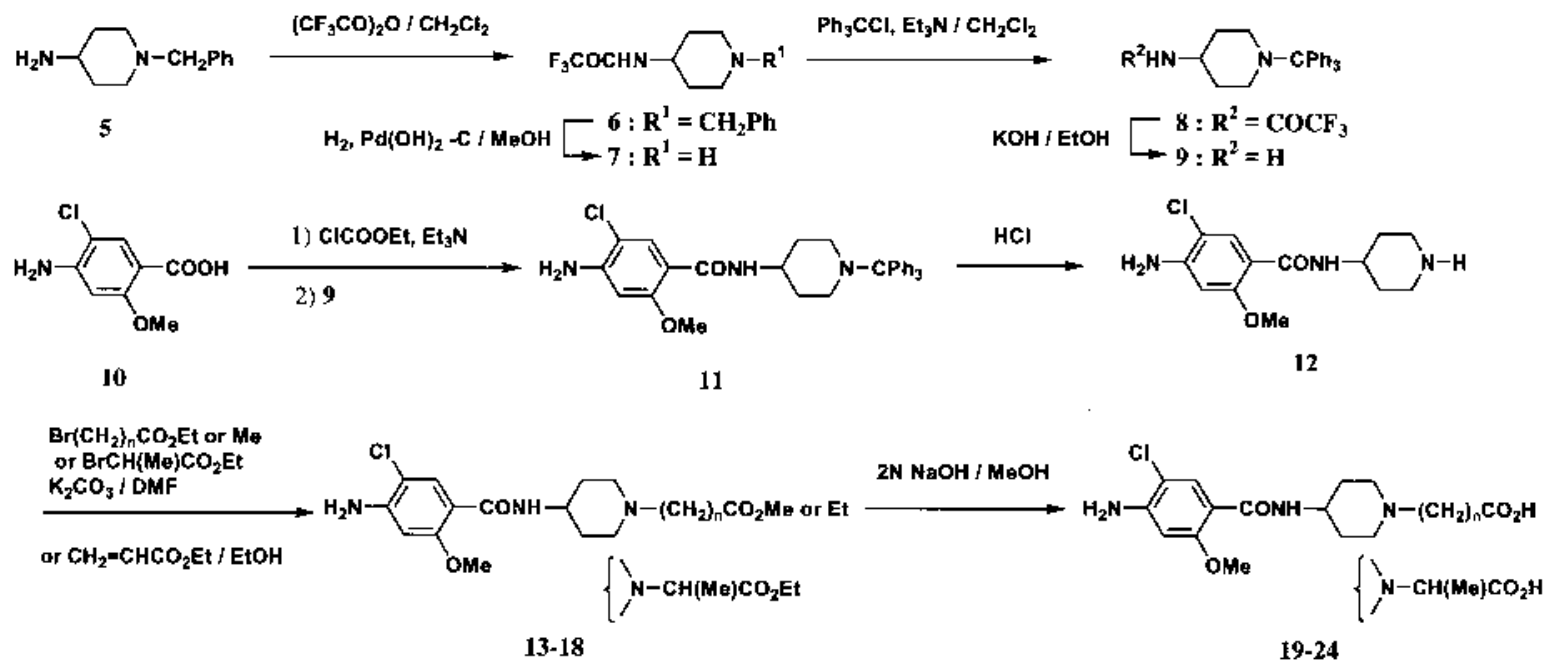

$\pi=1-5$

Chart 2

Method B

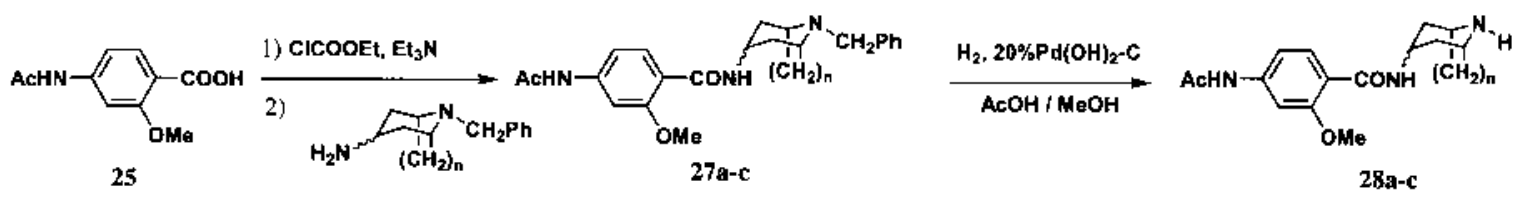

$26 \mathrm{a}-\mathrm{c}$
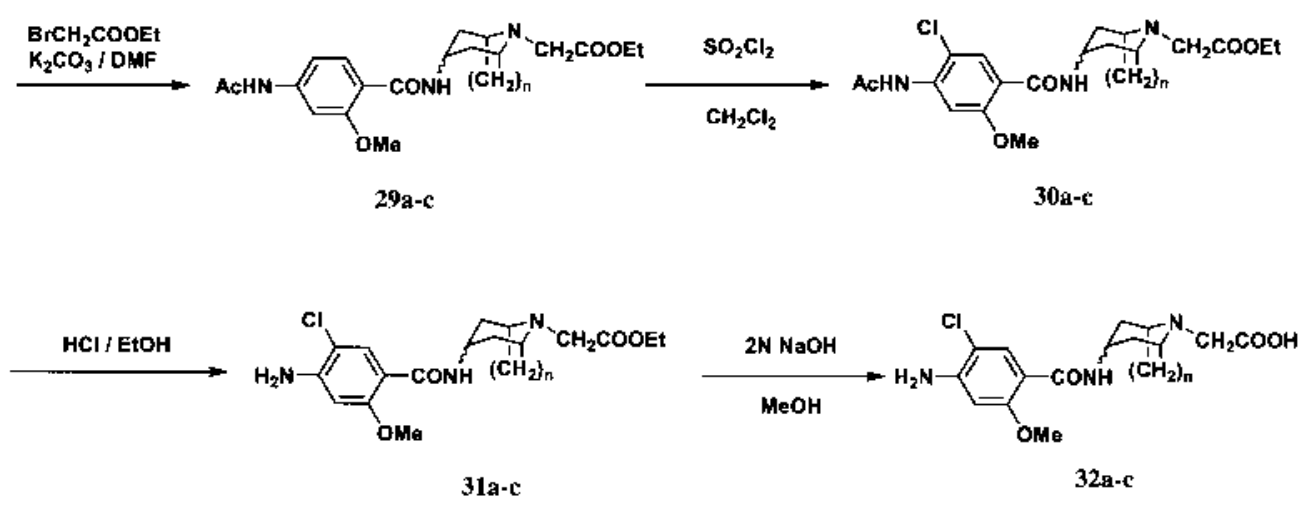

a: endo, $n=3 ; b$; exo, $n=3 ;$ c: exo, $n=2$

Chart 3

piperidinealkanecarboxylic acid side chains were prepared by method A. Firstly, 4-amino-1-benzylpiperidine (5) was treated with trifluoroacetic anhydride to give 6. Catalytic hydrogenolysis of $\mathbf{6}$ with Pearlman's catalyst, followed by condensation with trytyl chloride, afforded $\mathbf{8}$ via 7 . Then deacylation of 8 with $\mathrm{KOH}$ gave 4-amino-1-tritylpiperidine (9). Commercially available 4-amino-5-chloro-2-methoxybenzoic acid (10) was condensed with 9 to afford 11. Deprotection of 11 with hydrochloric acid gave the secondary amine (12), ${ }^{\text {) }}$ which was treated with ethyl or methyl $\omega$-bromoalkanecarboxylates, ethyl 2-bromopropionate or ethyl acrylate, to afford various esters $(\mathbf{1 3}-\mathbf{1 8})$. The esters $(\mathbf{1 3}-\mathbf{1 8})$ were hydrolyzed under basic conditions to provide the desired am- photeric benzamides (19-24).

Benzamides (32a-c), possessing endo- or exo-9-azabicyclo[3.3.1]nonane-9-acetic acid, or an exo-8-azabicyclo[3.2.1] octane-8-acetic acid side chain, were prepared by method B as shown in Chart 3. 4-Acetylamino-2-methoxybenzoic acid $(\mathbf{2 5})^{6)}$ was converted with ethyl chloroformate to the activated ester, which was condensed with endo- or exo-3-amino-9-benzyl-9-azabicyclo[3.3.1]nonane $(\mathbf{2 6 a}, \mathbf{b})^{7)}$ or exo-3-amino-8-benzyl-8-azabicyclo[3.2.1]octane $(\mathbf{2 6 c})^{7)}$ to afford benzamides 27a-c. Catalytic hydrogenolysis of 27a - c with Pearlman's catalyst gave secondary amines $28 \mathbf{a}-\mathbf{c}$, and the subsequent treatment with ethyl bromoacetate afforded compounds $29 \mathbf{a}-\mathbf{c}$. Chlorination of $29 \mathbf{a}-\mathbf{c}$ 
Method C
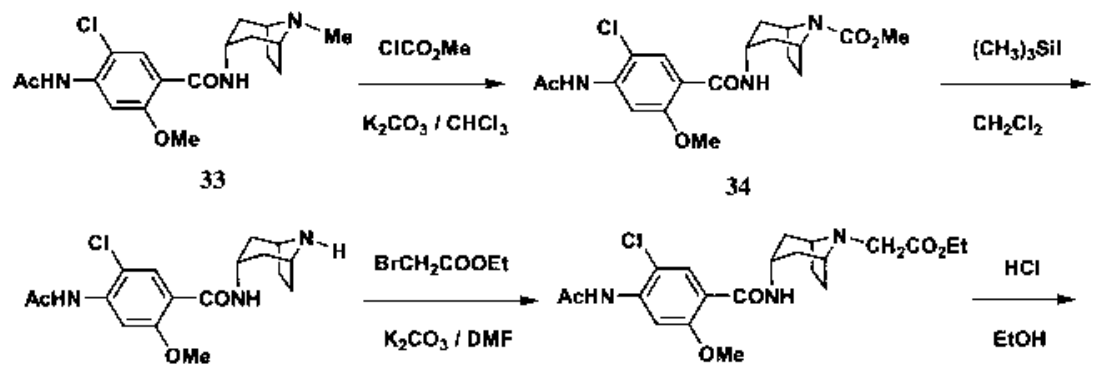

35

36

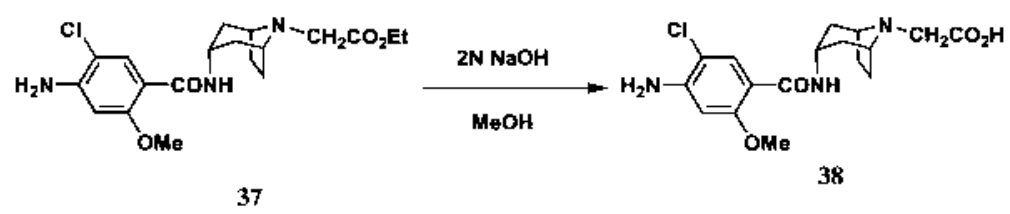

Chart 4

Method D

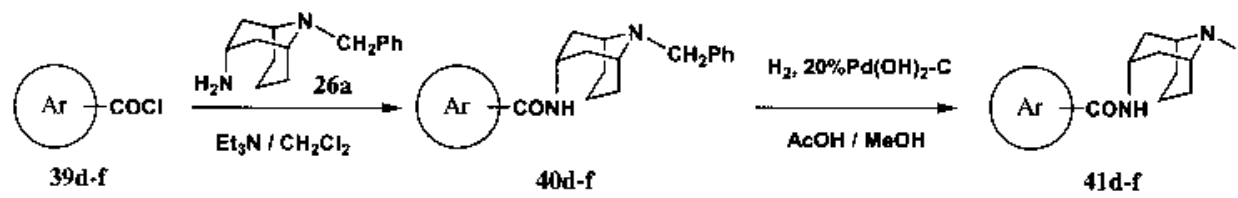

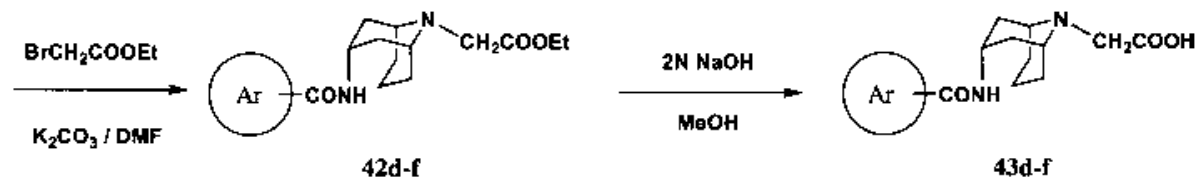

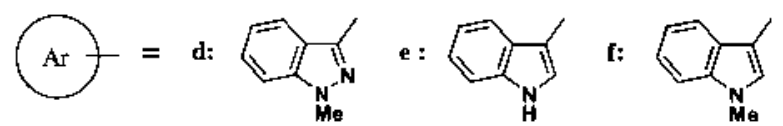

Chart 5

Melhod E<smiles>COc1cc(N)c(Cl)cc1C(=O)NC1CCN(CC(=O)O)CC1</smiles>

19

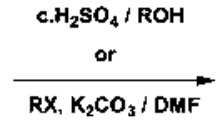

Chart 6

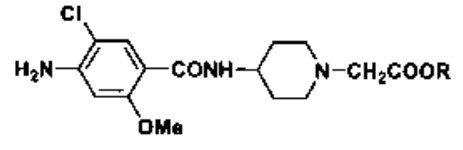

44-60 with sulfuryl chloride yielded $\mathbf{3 0 a}-\mathbf{c}$, which was deacetylated with hydrochloric acid to give compounds 31a-c. Basic hydrolysis of 31a-c afforded the desired amphoteric benzamides $(\mathbf{3 2} \mathbf{a}-\mathbf{c})$.

Benzamide (38), with an endo-8-azabicyclo[3.2.1] octane8 -acetic acid side chain, was synthesized by method $\mathrm{C}$ as shown in Chart 4. Treatment of endo-4-acetylamino-5chloro-2-methoxy- $N$-(8-methyl-8-azabicyclo[3.2.1]oct-3yl)benzamide $(\mathbf{3 3})^{7)}$ with methyl chloroformate gave urethane (34), which was exposed to trimethylsilyl iodide to yield 35. Compound 35 was treated with ethyl bromoacetate to afford 36, which was subsequently deacetylated with hydrochloric acid to obtain ester (37). Compound 37 was hydrolyzed with base to provide the desired amphoteric benzamide (38).

Heterocyclic carboxamides $(\mathbf{4 3 d}-\mathbf{f})$, each possessing an amphoteric side chain, were prepared by method D as shown in Chart 5. Acid chloride (39d-f $)^{8,9)}$ was condensed with amine (26a) to afford amides $(\mathbf{4 0 d}-\mathbf{f})$. Catalytic hydrogenolysis of $\mathbf{4 0 d}$ - f with Pearlman's catalyst, followed by conden- 
sation with ethyl bromoacetate, afforded esters $(\mathbf{4 2 d}-\mathbf{f})$ via secondary amines $(\mathbf{4 1 d}-\mathbf{f})$. The esters $(\mathbf{4 2 d}-\mathbf{f})$ were subsequently hydrolyzed with base to give the desired amphoteric carboxamides $(\mathbf{4 3 d}-\mathbf{f})$.

The ester prodrugs $(\mathbf{4 4 - 6 0})$ of 19 were prepared by method $\mathrm{E}$ as shown in Chart 6. Compound $\mathbf{1 9}$ was esterified with alcohol using an acid catalyst, or with various halides in
$\mathrm{N}, \mathrm{N}$-dimethylformamide (DMF) in the presence of potassium carbonate, to give the desired prodrugs $(\mathbf{4 4 - 6 0})$.

Physicochemical data for compounds 13-24, 28a-c, 29a-c, 30a-c, 31a-c, 32a-c, 36-38, 42d-f, 43d-f and $44-60$ are given in the Experimental section or in Tables $1-4$.

Table 1. Physicochemical Data for Monocyclic Esters and Carboxylic Acids 15-18, 20-24

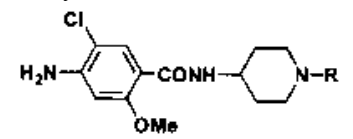

\begin{tabular}{|c|c|c|c|c|c|c|c|}
\hline \multirow{2}{*}{ Compd. } & \multirow{2}{*}{$\mathrm{R}$} & \multirow{2}{*}{ Method } & \multirow{2}{*}{$\mathrm{mp},{ }^{\circ} \mathrm{C}$ (recryst. solvent) ${ }^{a}$} & \multirow{2}{*}{ Formula } & \multicolumn{3}{|c|}{ Analysis (\%) Calcd (Found) } \\
\hline & & & & & $\mathrm{C}$ & $\mathrm{H}$ & $\mathrm{N}$ \\
\hline 15 & $\left(\mathrm{CH}_{2}\right)_{3} \mathrm{CO}_{2} \mathrm{Et}$ & A & $\begin{array}{l}188.5-191.5 \\
\text { (E) }\end{array}$ & $\mathrm{C}_{19} \mathrm{H}_{28} \mathrm{ClN}_{3} \mathrm{O}_{4} \cdot \mathrm{HCl}$ & $\begin{array}{r}52.54 \\
(52.18\end{array}$ & $\begin{array}{l}6.73 \\
6.66\end{array}$ & $\begin{array}{l}9.67 \\
9.75)\end{array}$ \\
\hline 16 & $\left(\mathrm{CH}_{2}\right)_{4} \mathrm{CO}_{2} \mathrm{Et}$ & A & $\begin{array}{l}202-203.5 \\
(\mathrm{E})\end{array}$ & $\mathrm{C}_{20} \mathrm{H}_{30} \mathrm{ClN}_{3} \mathrm{O}_{4} \cdot \mathrm{HCl} \cdot 1 \cdot 4 \mathrm{H}_{2} \mathrm{O}$ & $\begin{array}{r}53.04 \\
(52.99\end{array}$ & $\begin{array}{l}7.01 \\
6.95\end{array}$ & $\begin{array}{l}9.28 \\
9.21)\end{array}$ \\
\hline 17 & $\left(\mathrm{CH}_{2}\right)_{5} \mathrm{CO}_{2} \mathrm{Me}$ & A & $\begin{array}{l}208.5-210.5 \\
\text { (M) }\end{array}$ & $\mathrm{C}_{20} \mathrm{H}_{30} \mathrm{ClN}_{3} \mathrm{O}_{4} \cdot \mathrm{HCl} \cdot 5 \cdot 4 \mathrm{H}_{2} \mathrm{O}$ & $\begin{array}{r}51.01 \\
(51.06\end{array}$ & $\begin{array}{l}7.17 \\
7.03\end{array}$ & $\begin{array}{l}8.92 \\
8.99)\end{array}$ \\
\hline 18 & $\mathrm{CH}(\mathrm{Me}) \mathrm{CO}_{2} \mathrm{Et}$ & A & $\begin{array}{l}158-159 \\
\text { (E) }\end{array}$ & $\mathrm{C}_{18} \mathrm{H}_{26} \mathrm{ClN}_{3} \mathrm{O}_{4} \cdot \mathrm{C}_{4} \mathrm{H}_{4} \mathrm{O}_{4}{ }^{b)}$ & $\begin{array}{r}52.85 \\
(52.67\end{array}$ & $\begin{array}{l}6.05 \\
5.94\end{array}$ & $\begin{array}{l}8.40 \\
8.39)\end{array}$ \\
\hline 20 & $\left(\mathrm{CH}_{2}\right)_{2} \mathrm{CO}_{2} \mathrm{H}$ & A & $\begin{array}{l}218-219.5 \\
(\mathrm{~W})\end{array}$ & $\mathrm{C}_{16} \mathrm{H}_{22} \mathrm{ClN}_{3} \mathrm{O}_{4} \cdot \mathrm{HCl}$ & $\begin{array}{r}48.99 \\
(48.80\end{array}$ & $\begin{array}{l}5.91 \\
5.84\end{array}$ & $\begin{array}{l}10.71 \\
10.68)\end{array}$ \\
\hline 21 & $\left(\mathrm{CH}_{2}\right)_{3} \mathrm{CO}_{2} \mathrm{H}$ & A & $\begin{array}{l}228.5-231.5 \\
(W)\end{array}$ & $\mathrm{C}_{17} \mathrm{H}_{24} \mathrm{ClN}_{3} \mathrm{O}_{4} \cdot \mathrm{HCl} \cdot \mathrm{H}_{2} \mathrm{O}$ & $\begin{array}{r}48.12 \\
(47.97\end{array}$ & $\begin{array}{l}6.41 \\
6.34\end{array}$ & $\begin{array}{r}9.90 \\
10.12)\end{array}$ \\
\hline 22 & $\left(\mathrm{CH}_{2}\right)_{4} \mathrm{CO}_{2} \mathrm{H}$ & A & $\begin{array}{l}226-227.5 \\
(\mathrm{~W})\end{array}$ & $\mathrm{C}_{18} \mathrm{H}_{26} \mathrm{ClN}_{3} \mathrm{O}_{4} \cdot \mathrm{HCl} \cdot \mathrm{H}_{2} \mathrm{O}$ & $\begin{array}{r}49.32 \\
(49.18\end{array}$ & $\begin{array}{l}6.67 \\
6.45\end{array}$ & $\begin{array}{l}9.59 \\
9.54)\end{array}$ \\
\hline 23 & $\left(\mathrm{CH}_{2}\right)_{5} \mathrm{CO}_{2} \mathrm{H}$ & $\mathrm{A}$ & $\begin{array}{l}223-225 \\
(\mathrm{~W})\end{array}$ & $\mathrm{C}_{19} \mathrm{H}_{28} \mathrm{ClN}_{3} \mathrm{O}_{4} \cdot \mathrm{HCl} \cdot \mathrm{H}_{2} \mathrm{O}$ & $\begin{array}{r}50.45 \\
(50.33\end{array}$ & $\begin{array}{l}6.91 \\
6.84\end{array}$ & $\begin{array}{l}9.29 \\
9.25)\end{array}$ \\
\hline 24 & $\mathrm{CH}(\mathrm{Me}) \mathrm{CO}_{2} \mathrm{H}$ & A & $\begin{array}{l}246-247 \\
(\mathrm{~W})\end{array}$ & $\mathrm{C}_{16} \mathrm{H}_{22} \mathrm{ClN}_{3} \mathrm{O}_{4} \cdot 5 \cdot 4 \mathrm{H}_{2} \mathrm{O}$ & $\begin{array}{r}50.79 \\
(50.59\end{array}$ & $\begin{array}{l}6.53 \\
6.25\end{array}$ & $\begin{array}{l}11.11 \\
11.06)\end{array}$ \\
\hline
\end{tabular}

a) $\mathrm{E}=\mathrm{EtOH}, \mathrm{M}=\mathrm{MeOH}, \mathrm{W}=$ Water. b) Fumaric acid.

Table 2. Physicochemical Data for Bicyclic Compounds 28-32

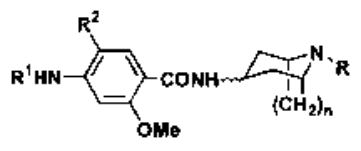

\begin{tabular}{|c|c|c|c|c|c|c|c|c|c|c|c|}
\hline \multirow{2}{*}{ Compd. } & \multirow{2}{*}{$n$} & \multirow{2}{*}{$\mathrm{R}^{1}$} & \multirow{2}{*}{$\mathrm{R}^{2}$} & \multirow{2}{*}{$R$} & \multirow{2}{*}{ endo/exo } & \multirow{2}{*}{ Method } & \multirow{2}{*}{$\mathrm{mp},{ }^{\circ} \mathrm{C}$ (recryst. solvent) $)^{a)}$} & \multirow{2}{*}{ Formula } & \multicolumn{3}{|c|}{ Analysis (\%) Calcd (Found) } \\
\hline & & & & & & & & & $\mathrm{C}$ & $\mathrm{H}$ & $\mathrm{N}$ \\
\hline $28 b$ & 3 & Ac & $\mathrm{H}$ & $\mathrm{H}$ & exo & B & $\begin{array}{l}194-196 \text { (dec.) } \\
\text { (M) }\end{array}$ & $\mathrm{C}_{18} \mathrm{H}_{25} \mathrm{~N}_{3} \mathrm{O}_{3} \cdot \mathrm{C}_{4} \mathrm{H}_{4} \mathrm{O}_{4}^{b)} \cdot 3 / 4 \mathrm{H}_{2} \mathrm{O}$ & $\begin{array}{r}57.32 \\
(57.13\end{array}$ & $\begin{array}{l}6.67 \\
6.58\end{array}$ & $\begin{array}{l}9.12 \\
9.12)\end{array}$ \\
\hline $28 \mathrm{c}$ & 2 & Ac & $\mathrm{H}$ & $\mathrm{H}$ & exo & B & $\begin{array}{l}223-225 \text { (dec.) } \\
\text { (M) }\end{array}$ & $\mathrm{C}_{17} \mathrm{H}_{23} \mathrm{~N}_{3} \mathrm{O}_{3} \cdot \mathrm{C}_{4} \mathrm{H}_{4} \mathrm{O}_{4}^{b)}$ & $\begin{array}{r}58.19 \\
(58.05\end{array}$ & $\begin{array}{l}6.28 \\
6.45\end{array}$ & $\begin{array}{l}9.69 \\
9.71)\end{array}$ \\
\hline 29b & 3 & Ac & $\mathrm{H}$ & $\mathrm{CH}_{2} \mathrm{CO}_{2} \mathrm{Et}$ & exo & B & oil & $\mathrm{C}_{22} \mathrm{H}_{31} \mathrm{~N}_{3} \mathrm{O}_{5}$ & $\begin{array}{r}417.2 \\
(417.2\end{array}$ & $2264^{d)}$ & \\
\hline $29 c$ & 2 & Ac & $\mathrm{H}$ & $\mathrm{CH}_{2} \mathrm{CO}_{2} \mathrm{Et}$ & exo & B & oil & $\mathrm{C}_{21} \mathrm{H}_{29} \mathrm{~N}_{3} \mathrm{O}_{5}$ & $\begin{array}{r}403.2 \\
(403.2\end{array}$ & 2107 & \\
\hline 30b & 3 & Ac & $\mathrm{Cl}$ & $\mathrm{CH}_{2} \mathrm{CO}_{2} \mathrm{Et}$ & exo & B & $\begin{array}{l}125-128 \\
(\mathrm{M})\end{array}$ & $\mathrm{C}_{22} \mathrm{H}_{30} \mathrm{~N}_{3} \mathrm{O}_{5} \cdot 3 / 4 \mathrm{C}_{4} \mathrm{H}_{4} \mathrm{O}_{4}^{b)} \cdot 7 / 4 \mathrm{H}_{2} \mathrm{O}$ & $\begin{array}{r}52.63 \\
(52.40\end{array}$ & $\begin{array}{l}6.45 \\
6.08\end{array}$ & $\begin{array}{l}7.37 \\
7.67)\end{array}$ \\
\hline 30c & 2 & Ac & $\mathrm{Cl}$ & $\mathrm{CH}_{2} \mathrm{CO}_{2} \mathrm{Et}$ & exo & B & $\begin{array}{l}174-175 \\
\text { (E) }\end{array}$ & $\mathrm{C}_{21} \mathrm{H}_{28} \mathrm{ClN}_{3} \mathrm{O}_{5} \cdot \mathrm{C}_{4} \mathrm{H}_{4} \mathrm{O}_{4}^{c)}$ & $\begin{array}{r}54.20 \\
(54.03\end{array}$ & $\begin{array}{l}5.82 \\
5.85\end{array}$ & $\begin{array}{l}7.58 \\
7.56)\end{array}$ \\
\hline 31b & 3 & $\mathrm{H}$ & $\mathrm{Cl}$ & $\mathrm{CH}_{2} \mathrm{CO}_{2} \mathrm{Et}$ & exo & B & $\begin{array}{l}161-164 \\
(\mathrm{IP}-\mathrm{DE})\end{array}$ & $\mathrm{C}_{20} \mathrm{H}_{28} \mathrm{ClN}_{3} \mathrm{O}_{4} \cdot 3 / 4 \mathrm{H}_{2} \mathrm{O}$ & $\begin{array}{r}56.73 \\
(56.73\end{array}$ & $\begin{array}{l}7.02 \\
6.63\end{array}$ & $\begin{array}{l}9.92 \\
9.96)\end{array}$ \\
\hline $31 \mathrm{c}$ & 2 & $\mathrm{H}$ & $\mathrm{Cl}$ & $\mathrm{CH}_{2} \mathrm{CO}_{2} \mathrm{Et}$ & exo & B & $\begin{array}{l}188.5-190 \\
(\mathrm{E}-\mathrm{DE})\end{array}$ & $\mathrm{C}_{19} \mathrm{H}_{26} \mathrm{ClN}_{3} \mathrm{O}_{4}$ & $\begin{array}{r}57.65 \\
(57.60\end{array}$ & $\begin{array}{l}6.62 \\
6.57\end{array}$ & $\begin{array}{l}10.61 \\
10.49)\end{array}$ \\
\hline $32 \mathrm{~b}$ & 3 & $\mathrm{H}$ & $\mathrm{Cl}$ & $\mathrm{CH}_{2} \mathrm{CO}_{2} \mathrm{H}$ & exo & B & $\begin{array}{l}250-252 \text { (dec.) } \\
\text { (M) }\end{array}$ & $\mathrm{C}_{18} \mathrm{H}_{24} \mathrm{ClN}_{3} \mathrm{O}_{4} \cdot 3 / 4 \mathrm{H}_{2} \mathrm{O}$ & $\begin{array}{r}54.68 \\
(54.68\end{array}$ & $\begin{array}{l}6.50 \\
6.25\end{array}$ & $\begin{array}{l}10.63 \\
10.94)\end{array}$ \\
\hline $32 \mathrm{c}$ & 2 & $\mathrm{H}$ & $\mathrm{Cl}$ & $\mathrm{CH}_{2} \mathrm{CO}_{2} \mathrm{H}$ & exo & B & $\begin{array}{l}273-276 \text { (dec.) } \\
(\mathrm{M}-\mathrm{DE})\end{array}$ & $\mathrm{C}_{17} \mathrm{H}_{22} \mathrm{ClN}_{3} \mathrm{O}_{4}$ & $\begin{array}{r}55.51 \\
(55.20\end{array}$ & $\begin{array}{l}6.03 \\
6.05\end{array}$ & $\begin{array}{l}11.42 \\
11.20)\end{array}$ \\
\hline
\end{tabular}

a) $\mathrm{DE}=\mathrm{Et}_{2} \mathrm{O}, \mathrm{DI}=$ iso- $\mathrm{Pr}_{2} \mathrm{O}, \mathrm{E}=\mathrm{EtOH}, \mathrm{IP}=$ iso- $\mathrm{PrOH}, \mathrm{M}=\mathrm{MeOH}, \mathrm{W}=$ Water. b) Fumaric acid. c) Maleic acid. d) High resolution mass spectra. 
Table 3. Physicochemical Data for Heterocyclic Compounds $\mathbf{4 2}-\mathbf{4 3}$

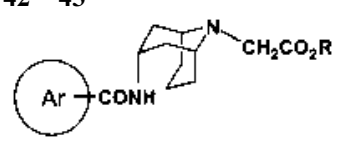

\begin{tabular}{|c|c|c|c|c|c|c|c|}
\hline \multirow{2}{*}{ Compd. } & \multirow{2}{*}{$\mathrm{R}$} & \multirow{2}{*}{ Method } & \multirow{2}{*}{$\mathrm{mp},{ }^{\circ} \mathrm{C}$ (recryst. solvent $\left.)^{a}\right)$} & \multirow{2}{*}{ Formula } & \multicolumn{3}{|c|}{ Analysis (\%) Calcd (Found) } \\
\hline & & & & & $\mathrm{C}$ & $\mathrm{H}$ & $\mathrm{N}$ \\
\hline $42 \mathrm{e}$ & $\mathrm{Et}$ & $\mathrm{D}$ & Oil & $\mathrm{C}_{21} \mathrm{H}_{27} \mathrm{~N}_{3} \mathrm{O}_{3}$ & \multicolumn{2}{|c|}{$\begin{array}{c}369.2052^{b)} \\
(369.2057)\end{array}$} & \\
\hline $42 \mathrm{f}$ & $\mathrm{Et}$ & $\mathrm{D}$ & $\begin{array}{l}155-156 \\
\text { (E) }\end{array}$ & $\mathrm{C}_{22} \mathrm{H}_{29} \mathrm{~N}_{3} \mathrm{O}_{3}$ & $\begin{array}{r}68.90 \\
(68.60\end{array}$ & $\begin{array}{l}7.62 \\
7.48\end{array}$ & $\begin{array}{l}10.96 \\
11.06)\end{array}$ \\
\hline $43 \mathrm{e}$ & $\mathrm{H}$ & $\mathrm{D}$ & $\begin{array}{l}235-240(\text { dec. }) \\
(W)\end{array}$ & $\begin{array}{l}\mathrm{C}_{19} \mathrm{H}_{23} \mathrm{~N}_{3} \mathrm{O}_{3} \cdot \\
\mathrm{HCl}\end{array}$ & $\begin{array}{r}60.39 \\
(60.39\end{array}$ & $\begin{array}{l}6.40 \\
6.42\end{array}$ & $\begin{array}{l}11.12 \\
11.22)\end{array}$ \\
\hline $43 f$ & $\mathrm{H}$ & $\mathrm{D}$ & $\begin{array}{l}200-202 \\
(\mathrm{~W})\end{array}$ & $\begin{array}{l}\mathrm{C}_{20} \mathrm{H}_{25} \mathrm{~N}_{3} \mathrm{O}_{3} \cdot \\
\mathrm{HCl} \cdot \mathrm{H}_{2} \mathrm{O}\end{array}$ & $\begin{array}{r}60.33 \\
(60.27\end{array}$ & $\begin{array}{l}7.36 \\
7.39\end{array}$ & $\begin{array}{l}9.59 \\
9.71)\end{array}$ \\
\hline
\end{tabular}

a) $\mathrm{E}=\mathrm{EtOH}, \mathrm{W}=$ Water. b) High resolution mass spectra.

Table 4. Physicochemical Data for Prodrugs 46-60

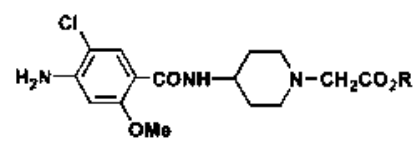

\begin{tabular}{|c|c|c|c|c|c|c|c|}
\hline \multirow{2}{*}{ Compd. } & \multirow{2}{*}{$\mathrm{R}$} & \multirow{2}{*}{ Method } & \multirow{2}{*}{$\mathrm{mp},{ }^{\circ} \mathrm{C}$ (recryst. solvent) $\left.{ }^{a}\right)$} & \multirow{2}{*}{ Formula } & \multicolumn{3}{|c|}{ Analysis (\%) Calcd (Found) } \\
\hline & & & & & $\mathrm{C}$ & $\mathrm{H}$ & $\mathrm{N}$ \\
\hline 46 & $n-\mathrm{Bu}$ & $\mathrm{F}$ & $\begin{array}{c}209-211.5 \\
\text { (IP) }\end{array}$ & $\begin{array}{l}\mathrm{C}_{19} \mathrm{H}_{28} \mathrm{ClN}_{3} \mathrm{O}_{4} \\
\cdot \mathrm{CH}_{4} \mathrm{O}_{3} \mathrm{~S}^{b)}\end{array}$ & $\begin{array}{r}48.63 \\
(48.37\end{array}$ & $\begin{array}{l}6.53 \\
6.81\end{array}$ & $\begin{array}{l}8.51 \\
8.44)\end{array}$ \\
\hline 47 & $n$-Pentyl & $\mathrm{F}$ & $\begin{array}{l}202.5-203 \\
\text { (IP) }\end{array}$ & $\begin{array}{l}\mathrm{C}_{20} \mathrm{H}_{30} \mathrm{ClN} \mathrm{ClN}_{3} \mathrm{O}_{4} \\
\cdot \mathrm{CH}_{4} \mathrm{O}_{3} \mathrm{~S}^{b)}\end{array}$ & $\begin{array}{r}49.65 \\
(49.46\end{array}$ & $\begin{array}{l}6.75 \\
6.98\end{array}$ & $\begin{array}{l}8.27 \\
8.22)\end{array}$ \\
\hline 48 & $n$-Hex & $\mathrm{F}$ & $\begin{array}{c}133-137 \\
\text { (IP) }\end{array}$ & $\begin{array}{l}\mathrm{C}_{21} \mathrm{H}_{32} \mathrm{ClN}_{3} \mathrm{O}_{4} \cdot \mathrm{HCl} \\
\cdot 1 / 2 \mathrm{H}_{2} \mathrm{O}\end{array}$ & $\begin{array}{r}53.50 \\
(53.26\end{array}$ & $\begin{array}{l}7.27 \\
7.27\end{array}$ & $\begin{array}{l}8.91 \\
8.82)\end{array}$ \\
\hline 49 & iso-Pr & $\mathrm{F}$ & $\begin{array}{l}125-130 \\
\text { (IP) }\end{array}$ & $\begin{array}{l}\mathrm{C}_{18} \mathrm{H}_{26} \mathrm{ClN}_{3} \mathrm{O}_{4} \cdot \mathrm{HCl} \\
\cdot 2 \mathrm{H}_{2} \mathrm{O}\end{array}$ & $\begin{array}{r}47.37 \\
(47.46\end{array}$ & $\begin{array}{l}6.85 \\
6.67\end{array}$ & $\begin{array}{l}9.21 \\
9.14)\end{array}$ \\
\hline 50 & iso- $\mathrm{Bu}$ & $\mathrm{F}$ & $\begin{array}{l}207-208 \\
\text { (IP) }\end{array}$ & $\begin{array}{l}\mathrm{C}_{19} \mathrm{H}_{28} \mathrm{ClN}_{3} \mathrm{O}_{4} \\
\cdot \mathrm{CH}_{4} \mathrm{O}_{3} \mathrm{~S}^{b)} \cdot 1 / 4 \mathrm{H}_{2} \mathrm{O}\end{array}$ & $\begin{array}{r}48.19 \\
(48.14\end{array}$ & $\begin{array}{l}6.57 \\
6.80\end{array}$ & $\begin{array}{l}8.43 \\
8.36)\end{array}$ \\
\hline 51 & iso-Pentyl & $\mathrm{F}$ & $\begin{array}{l}199.5-201 \\
\text { (IP) }\end{array}$ & $\begin{array}{l}\mathrm{C}_{20} \mathrm{H}_{30} \mathrm{ClN} \mathrm{N}_{3} \mathrm{O}_{4} \\
\cdot \mathrm{CH}_{4} \mathrm{O}_{3} \mathrm{~S}^{b)} \cdot 3 / 4 \mathrm{H}_{2} \mathrm{O}\end{array}$ & $\begin{array}{r}48.36 \\
(48.24\end{array}$ & $\begin{array}{l}6.86 \\
6.64\end{array}$ & $\begin{array}{l}8.06 \\
8.02)\end{array}$ \\
\hline 52 & $\mathrm{CH}_{2} \mathrm{CH}_{2} \mathrm{OMe}$ & $\mathrm{F}$ & $\begin{array}{c}147-150 \\
\text { (E) }\end{array}$ & $\begin{array}{l}\mathrm{C}_{18} \mathrm{H}_{26} \mathrm{ClN}_{3} \mathrm{O}_{5} \\
\cdot \mathrm{C}_{4} \mathrm{H}_{4} \mathrm{O}_{4}^{c)} \cdot 1 / 2 \mathrm{H}_{2} \mathrm{O}\end{array}$ & $\begin{array}{r}50.34 \\
(50.40\end{array}$ & $\begin{array}{l}5.95 \\
5.89\end{array}$ & $\begin{array}{l}8.00 \\
8.03)\end{array}$ \\
\hline 53 & Benzyl & $\mathrm{F}$ & $\begin{array}{c}174-175 \\
\text { (E) }\end{array}$ & $\begin{array}{l}\mathrm{C}_{22} \mathrm{H}_{26} \mathrm{ClN}_{3} \mathrm{O}_{4} \\
\cdot \mathrm{C}_{4} \mathrm{H}_{4} \mathrm{O}_{4}^{c)}\end{array}$ & $\begin{array}{r}56.99 \\
(56.98\end{array}$ & $\begin{array}{l}5.52 \\
5.72\end{array}$ & $\begin{array}{l}7.67 \\
7.67)\end{array}$ \\
\hline 54 & $\mathrm{CH}_{2} \mathrm{COMe}$ & $\mathrm{F}$ & $\begin{array}{c}174-175 \\
\text { (E) }\end{array}$ & $\begin{array}{l}\mathrm{C}_{18} \mathrm{H}_{24} \mathrm{ClN}_{3} \mathrm{O}_{5} \\
\cdot \mathrm{CH}_{4} \mathrm{O}_{3} \mathrm{~S}^{b)} \cdot 3 / 4 \mathrm{H}_{2} \mathrm{O}\end{array}$ & $\begin{array}{r}44.97 \\
(44.88\end{array}$ & $\begin{array}{l}5.86 \\
5.75\end{array}$ & $\begin{array}{l}8.28 \\
8.19)\end{array}$ \\
\hline 55 & $\mathrm{CH}_{2} \mathrm{CO}_{2} \mathrm{Et}$ & $\mathrm{F}$ & $\begin{array}{c}196-201 \\
\text { (E) }\end{array}$ & $\begin{array}{l}\mathrm{C}_{19} \mathrm{H}_{26} \mathrm{ClN}_{3} \mathrm{O}_{6} \\
\cdot \mathrm{CH}_{4} \mathrm{O}_{3} \mathrm{~S}^{b)}\end{array}$ & $\begin{array}{r}45.84 \\
(45.66\end{array}$ & $\begin{array}{l}5.77 \\
5.82\end{array}$ & $\begin{array}{l}8.02 \\
7.88)\end{array}$ \\
\hline 56 & $\mathrm{CH}_{2} \mathrm{CONMe}_{2}$ & $\mathrm{~F}$ & $\begin{array}{c}190-191 \\
\text { (A) }\end{array}$ & $\mathrm{C}_{19} \mathrm{H}_{27} \mathrm{ClN}_{4} \mathrm{O}_{5}$ & $\begin{array}{r}53.46 \\
(53.59\end{array}$ & $\begin{array}{l}6.37 \\
6.50\end{array}$ & $\begin{array}{l}13.12 \\
13.31)\end{array}$ \\
\hline 57 & & $\mathrm{~F}$ & $\begin{array}{c}124-129.5 \\
\text { (E) }\end{array}$ & $\begin{array}{l}\mathrm{C}_{19} \mathrm{H}_{26} \mathrm{Cl}_{\mathrm{N}} 3_{\mathrm{O}} 6 \\
\cdot \mathrm{C}_{4} \mathrm{H}_{4} \mathrm{O}_{4}{ }^{c)} \cdot 1 / 4 \mathrm{H}_{2} \mathrm{O}\end{array}$ & $\begin{array}{r}50.37 \\
(50.42\end{array}$ & $\begin{array}{l}5.61 \\
5.47\end{array}$ & $\begin{array}{l}7.66 \\
7.73)\end{array}$ \\
\hline 58 & & $\mathrm{~F}$ & $\begin{array}{c}160-164 \\
\text { (E) }\end{array}$ & $\begin{array}{l}\mathrm{C}_{21} \mathrm{H}_{30} \mathrm{ClN}_{3} \mathrm{O}_{6} \cdot \mathrm{HCl} \\
\cdot 5 / 4 \mathrm{H}_{2} \mathrm{O}\end{array}$ & $\begin{array}{r}48.98 \\
(48.74\end{array}$ & $\begin{array}{l}6.56 \\
6.25\end{array}$ & $\begin{array}{l}8.16 \\
8.20)\end{array}$ \\
\hline 59 & & $\mathrm{~F}$ & $\begin{array}{c}152-156.5 \\
(\mathrm{E})\end{array}$ & $\begin{array}{l}\mathrm{C}_{21} \mathrm{H}_{30} \mathrm{ClN}_{3} \mathrm{O}_{7} \cdot 2 \mathrm{HCl} \\
\cdot 1 / 4 \mathrm{H}_{2} \mathrm{O}\end{array}$ & $\begin{array}{r}45.91 \\
(45.81\end{array}$ & $\begin{array}{l}5.96 \\
5.83\end{array}$ & $\begin{array}{l}7.65 \\
7.70)\end{array}$ \\
\hline 60 & & $\mathrm{~F}$ & $\begin{array}{c}118.5-126 \\
(\mathrm{M}-\mathrm{IP})\end{array}$ & $\begin{array}{l}\mathrm{C}_{24} \mathrm{H}_{34} \mathrm{ClN}_{3} \mathrm{O}_{7} \cdot \mathrm{HCl} \\
\cdot \mathrm{H}_{2} \mathrm{O}\end{array}$ & $\begin{array}{r}50.89 \\
(50.88\end{array}$ & $\begin{array}{l}6.58 \\
6.29\end{array}$ & $\begin{array}{l}7.42 \\
7.42)\end{array}$ \\
\hline
\end{tabular}

a) $\mathrm{A}=\mathrm{AcOEt}, \mathrm{E}=\mathrm{EtOH}, \mathrm{IP}=$ iso-PrOH, $\mathrm{M}=\mathrm{MeOH}$. b) Methanesulfonic acid. c) Fumaric acid. 


\section{Results and Discussion}

The gastrointestinal prokinetic activities of all amphoteric compounds (19-24, 32a $-\mathbf{c}, \mathbf{3 8}, \mathbf{4 3 d}-\mathbf{f})$ in conscious dogs were determined using the method of Z. Itoh. ${ }^{10)}$ The gastric antrum motility of each compound was quantified by determining a motor index, which was equivalent to the integrated area between the contractile wave and the base line, and expressed as a symbol based on a percentage against the basal motor index. Colonic motility was expressed by the \% ratio of the number of dogs, in which the giant contraction on the ascending colon was observed, versus the tested dogs. The dopamine $\mathrm{D}_{2}$ receptor binding affinity, which was responsible for the side effect of benzamides, such as $\mathbf{1 a}$ and $\mathbf{1 b}$, was estimated and expressed by $\mathrm{pIC}_{50}$ (-logarithm of inhibitory concentration $50 \%$ ) values. The pharmacological results are given in Tables 5-7.

Firstly, we examined monocyclic amino compounds (Table 5). Amphoteric compounds (19-23) with a straight methylene chain, except for 22, showed more potent gastro- and colon-prokinetic activities than $N$-methyl analog $(\mathbf{6 1})^{11)}$ or 1a, and elongation of the methylene chain led to a decrease in both prokinetic activities. Compound 19 especially exhib- ited excellent gastro- and colon-prokinetic activities in comparison with 1b. In addition, the introduction of a methyl group (24) into the $\alpha$-position of the carboxy group in 19 led to a slight reduction in gastro- and colon-prokinetic activities. These results suggested that the distance between the basic nitrogen atom and the carboxy group would be an important factor for gastro- and colon-prokinetic activities.

The dopamine $\mathrm{D}_{2}$ receptor affinity of the $\mathrm{N}$-methyl analog (61) was moderate $\left(\mathrm{pIC}_{50}=5.7\right)$, while none of the amphoteric compounds showed significant affinity. This result suggested that amphoteric-ionization caused a decrease in $\mathrm{D}_{2}$ binding affinity.

We selected the acetic acid moiety $(n=1)$ as a substituent on the basic nitrogen atom for further optimization, since $\mathbf{1 9}$ exhibited the most excellent gastro- and colon-prokinetic activities among monocyclic amphoteric compounds (19-24).

Secondly, we addressed our attention to the compounds with a bicyclic amine moiety. As shown in Table 6, bicyclic amphoteric compounds $(\mathbf{3 2 a}-\mathbf{c}, \mathbf{3 8})$ showed similar or less potent gastro- or colon-prokinetic activity in comparison with the corresponding $N$-methyl analogs $\left.(\mathbf{6 2}-\mathbf{6 5})^{7}\right)$ in contrast to the case of monocyclic compounds. Especially, 32b

Table 5. Pharmacological Data for Monocyclic Benzamides

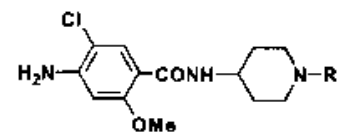

\begin{tabular}{|c|c|c|c|c|c|c|}
\hline \multirow{2}{*}{ Compd } & \multirow{2}{*}{$\mathrm{R}$} & \multicolumn{2}{|c|}{ 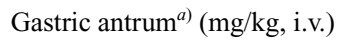 } & \multicolumn{2}{|c|}{ Ascending $\operatorname{colon}^{b)}(\mathrm{mg} / \mathrm{kg}$, i.v. $)$} & \multirow{2}{*}{$\mathrm{D}_{2}$ binding $\mathrm{pIC}_{50}$} \\
\hline & & 0.1 & 1.0 & 0.1 & 1.0 & \\
\hline 19 & $\mathrm{CH}_{2} \mathrm{CO}_{2} \mathrm{H}$ & ++ & ++ & 75 & 100 & $<4$ \\
\hline 20 & $\left(\mathrm{CH}_{2}\right)_{2} \mathrm{CO}_{2} \mathrm{H}$ & ++ & ++ & 0 & 25 & $<4$ \\
\hline 21 & $\left(\mathrm{CH}_{2}\right)_{3} \mathrm{CO}_{2} \mathrm{H}$ & + & ++ & 0 & 100 & $<4$ \\
\hline 22 & $\left(\mathrm{CH}_{2}\right)_{4} \mathrm{CO}_{2} \mathrm{H}$ & NT & - & NT & 0 & $<4$ \\
\hline 23 & $\left(\mathrm{CH}_{2}\right)_{5} \mathrm{CO}_{2} \mathrm{H}$ & - & ++ & 0 & 50 & 4.4 \\
\hline 24 & $\mathrm{CH}(\mathrm{Me}) \mathrm{CO}_{2} \mathrm{H}$ & + & + & 0 & 75 & $<4$ \\
\hline 61 & $\mathrm{Me}$ & - & + & 0 & 0 & 5.7 \\
\hline \multicolumn{2}{|c|}{ Metoclopramide (1a) } & - & + & 0 & 0 & 6.7 \\
\hline \multicolumn{2}{|c|}{ Cisapride (1b) } & + & ++ & 0 & 25 & 7.0 \\
\hline
\end{tabular}

a) The symbols have the following meanings:,$++ 150 \%$ or more;,$+ 125 \%$ to $150 \%$; - , less than $125 \%$; NT, not tested. $b$ ) $\%$ ratio of number of dogs in which giant contraction was observed versus the tested dogs.

Table 6. Pharmacological Data for Bicyclic Benzamides

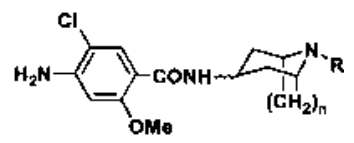

\begin{tabular}{|c|c|c|c|c|c|c|c|c|}
\hline \multirow{2}{*}{ Compd. } & \multirow{2}{*}{$\mathrm{n}$} & \multirow{2}{*}{$\mathrm{R}$} & \multirow{2}{*}{ endo/exo } & \multicolumn{2}{|c|}{$\begin{array}{l}\left.\text { Gastric antrum }^{a}\right) \\
(\mathrm{mg} / \mathrm{kg}, \text { i.v. })\end{array}$} & \multicolumn{2}{|c|}{$\begin{array}{l}\text { Ascending colon }{ }^{b)} \\
(\mathrm{mg} / \mathrm{kg}, \text { i.v. })\end{array}$} & \multirow{2}{*}{$\mathrm{D}_{2}$ binding $\mathrm{pIC}_{5 \mathrm{c}}$} \\
\hline & & & & 0.1 & 1.0 & 0.1 & 1.0 & \\
\hline $32 a$ & 3 & $\mathrm{CH}_{2} \mathrm{CO}_{2} \mathrm{H}$ & endo & + & ++ & 0 & 75 & 5.0 \\
\hline $32 b$ & 3 & $\mathrm{CH}_{2} \mathrm{CO}_{2} \mathrm{H}$ & exo & NT & - & NT & 0 & $<4$ \\
\hline $32 \mathrm{c}$ & 2 & $\mathrm{CH}_{2} \mathrm{CO}_{2} \mathrm{H}$ & exo & + & ++ & 33 & 67 & $<4$ \\
\hline 38 & 2 & $\mathrm{CH}_{2} \mathrm{CO}_{2} \mathrm{H}$ & endo & - & ++ & 0 & 100 & $<4$ \\
\hline 62 & 3 & $\mathrm{Me}$ & endo & + & ++ & 0 & 50 & 5.9 \\
\hline 63 & 3 & $\mathrm{Me}$ & exo & + & ++ & 0 & 0 & 6.3 \\
\hline 64 & 2 & $\mathrm{Me}$ & exo & + & ++ & 67 & 67 & 6.2 \\
\hline 65 & 2 & $\mathrm{Me}$ & endo & ++ & ++ & 0 & 33 & $<4$ \\
\hline
\end{tabular}

$a, b)$ See footnote $a$ and $b$ in Table 5 . 
Table 7. Pharmacological Data for Heterocyclic Carboxamides

\begin{tabular}{|c|c|c|c|c|}
\hline \multirow[t]{2}{*}{ Compd. } & \multirow[t]{2}{*}{$\mathrm{R}$} & $\begin{array}{l}\text { Gastric antrum }^{a)} \\
(\mathrm{mg} / \mathrm{kg}, \text { i.v. })\end{array}$ & $\begin{array}{l}\text { Ascending colon }{ }^{b)} \\
(\mathrm{mg} / \mathrm{kg}, \text { i.v. })\end{array}$ & \multirow[t]{2}{*}{$\mathrm{D}_{2}$ binding $\mathrm{pIC}_{5}$} \\
\hline & & 1.0 & 1.0 & \\
\hline 66 & $\mathrm{Me}$ & - & 0 & $<4$ \\
\hline 43d & $\mathrm{CH}_{2} \mathrm{COOH}$ & - & 0 & $<4$ \\
\hline 67 & $\mathrm{Me}$ & - & 0 & $<4$ \\
\hline $43 e$ & $\mathrm{CH}_{2} \mathrm{COOH}$ & - & 0 & $<4$ \\
\hline 68 & $\mathrm{Me}$ & - & 0 & 4.2 \\
\hline $43 f$ & $\mathrm{CH}_{2} \mathrm{COOH}$ & - & 0 & $<4$ \\
\hline
\end{tabular}

$a, b)$ See footnote $a$ and $b$ in Table 5 .

Table 8. Penetration of Compound 19 and Cisapride into Brain in Mice

\begin{tabular}{lrcc}
\hline \hline Compd. & $\begin{array}{c}\text { Plasma concentration } \\
(\mu \mathrm{g} / \mathrm{ml})\end{array}$ & $\begin{array}{c}\text { Brain concentration } \\
(\mu \mathrm{g} / \mathrm{ml})\end{array}$ & Brain/Plasma \\
\hline $\mathbf{1 9}$ & $23.25 \pm 1.32$ & $0.42 \pm 0.059$ & 0.018 \\
Cisapride $(\mathbf{1 b})$ & $2.24 \pm 0.46$ & $5.73 \pm 1.77$ & 2.40 \\
\hline
\end{tabular}

showed no significant gastro- and colon-prokinetic activities. Concerning $\mathrm{D}_{2}$ binding affinity, bicyclic amphoteric compounds (32a-c, 38) showed less potent affinity than the corresponding bicyclic $N$-methyl derivatives (62-65), and amphoteric-ionization of bicyclic compounds was found to cause the decrease in dopamine $\mathrm{D}_{2}$ affinity. This observation was consistent with the previous result obtained from monocyclic compounds.

Also examined were the replacements of the benzene ring of 32a, the most potent gastro- and colon-prokinetic active compound among the bicyclic amphoteric compounds, by some heterocyclic rings (Table 7). These replacements caused the disappearance in both gastrointestinal prokinetic activity and dopamine $\mathrm{D}_{2}$ affinity in not only $N$-methyl analogs (66 - 68) but also the corresponding amphoteric compounds (43d-f). Consequently, the benzene ring of $\mathbf{3 2 a}$ seemed to be essential for the gastrointestinal prokinetic activity.

On the basis of the above screening results, 19, with an amphoteric monocyclic side chain, was selected as the candidate for a novel gastrointestinal prokinetic agent, exhibiting both the gastro- and colon-prokinetic activities without $D_{2}$ binding affinity. Furthermore, we examined its penetration into the central nervous systems (CNS). As shown in Table 8, $\mathbf{1 9}$ showed a 100 times lower brain/plasma ratio than $\mathbf{1 b}$ and thus amphoteric-ionization was also found to be effective in lowering the penetration into the brain. Accordingly, 19 was expected to show no significant CNS side effect.

5-HT 4 Receptor Agonist Activity and Conformational Analysis In order to clarify the mode of action for 19, the
Table 9. Effect of SB-207266 on Gastrointestinal Contraction Induced by Intravenous Compound 19 Administration in Conscious Dogs

\begin{tabular}{lccc}
\hline \hline Compd. & $\begin{array}{c}\text { Dose } \\
(\mathrm{mg} / \mathrm{kg}, \text { i.v. })\end{array}$ & Gastric antrum $^{a)}$ & Ascending colon $^{b)}$ \\
\hline $\mathbf{1 9}$ & 1.0 & ++ & 100 \\
$\mathbf{1 9}+$ SB-207266 & $1.0+0.1$ & - & 0 \\
\hline
\end{tabular}

$a, b)$ See footnote $a$ and $b$ in Table 5 .

influence of the selective $5-\mathrm{HT}_{4}$ antagonist, SB-207266, ${ }^{12)}$ on the gastric and colonic contractions induced by 19 was evaluated. As shown in Table 9, the selective 5- $\mathrm{HT}_{4}$ antagonist blocked both gastric and colonic contractions. This result suggested that the $5-\mathrm{HT}_{4}$ receptor agonist activity would participate in the mechanism for the gastrointestinal prokinetic effect of 19.

The result shown in Table 9 allowed us to examine the relationship between gastrointestinal effects and $5-\mathrm{HT}_{4}$ agonist activity by conformational analysis.

Serotonin $5-\mathrm{HT}_{4}$ agonist activity of 19, 24, 32a-c and 38 was evaluated by their effects on carbachol-induced tone in rat esophagus and expressed as the negative logarithm of the molar concentration that exhibited $50 \%$ relaxation to the carbachol-induced contraction $\left(\mathrm{pEC}_{50}\right)$, as shown in Table 10 .

On the other hand, we implemented the conformational analysis of 19, 24, 32a-c and 38 according to the method of López-Rodríguez et al. ${ }^{13)}$ The molecules were built de novo in their protonated forms, which are believed to be bioactive forms, using the CAChe system, ${ }^{14)}$ and their geometry was optimized by the MM2 force field of the CAChe system. For the first purpose, we applied a systematic conformational analysis around four rotatable bonds, as shown in Fig. 1, and calculated the energy by $15^{\circ}$ stepwise increments of the dihedral angles. Then the lower energy conformers of each compound were energy-minimized by the MM2 force field. We tried to identify the lowest energy conformer of each compound accordingly. Generally, the oxygen atom substituted at 
the ortho position of the benzamide is considered to form an intramolecular hydrogen bond with the $\mathrm{NH}$ of the amide group. Concerning the dihedral angle $(\tau)$, defined by $[\mathrm{C} 1-$ C2-C3-O4] (see Fig. 1), we selected only the conformation of each compound whose $\tau$ was near $180^{\circ}$. López-Rodríguez et al. studied a $5-\mathrm{HT}_{4}$ pharmacophore model by their conformational analysis with various types of $5-\mathrm{HT}_{4}$ ligands. They proposed four essential criteria for active conformation as shown in Fig. 2: 1) the basic nitrogen atom situated at an average distance of $8.0 \pm 0.1 \AA$ from the centroid of the benzene ring $(\mathrm{Ar}-\mathrm{N})$; 2) the oxygen atom of the amide's carbonyl group situated at an average distance of $3.6 \pm 0.1 \AA$ from the centroid of the benzene ring $(\mathrm{Ar}-\mathrm{O}) ; 3)$ the oxygen atom of the amide's carbonyl group situated at an average distance of $5.4 \pm 0.1 \AA$ from the basic nitrogen atom $(\mathrm{O}-\mathrm{N})$; and (4) the basic nitrogen atom deviated at a distance of 3.6-4.0 $\AA$ from the plane of the benzene ring (h). To identify the active conformation, we actually performed a conformational analysis and energy minimization of each compound around the dihedral angle $(\theta)$, defined by [C3-N5-C6-C7] (see Fig. 1) of each compound, by $1^{\circ}$ stepwise increments of the dihedral angle, and then examined to see if the selected conformers of each compound were adapted to four structural criteria in the pharmacophore model, as described above.

Except for the deviations (the criterion 4); h), the structural parameters of 19, 24, 32b and 32c corresponded well with the above three criteria ( 1 to 3 ) of the $5-\mathrm{HT}_{4}$ pharmacophore model, but the 5- $\mathrm{HT}_{4}$ agonist activity of $\mathbf{2 4}, \mathbf{3 2} \mathbf{b}$ and 32c was weaker than that of compound 19. The $\alpha$-methyl group of $\mathbf{2 4}$ and the alkylene-bridged chains of exo-bicyclic compounds $(32 \mathbf{b}, 32 \mathbf{c})$ were presumed to situate at the same side of their amide carbonyl groups and which might disturb the tight interaction in the binding mode between the ligand

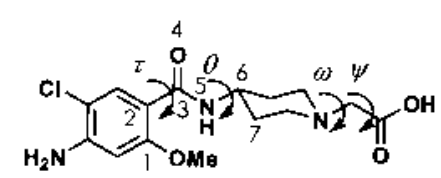

Fig. 1 and 5- $\mathrm{HT}_{4}$ receptor for enhancing $5-\mathrm{HT}_{4}$ agonist activity (see Fig. 3). The distances $\mathrm{Ar}-\mathrm{N}$ of endo-bicyclic compounds (32a, 38) were also found to be shorter than that of monocyclic compound (19), and it seemed to be one of the reasons they showed weak 5- $\mathrm{HT}_{4}$ agonist activity in comparison with 19. On the other hand, 5- $\mathrm{HT}_{4}$ agonist activities of all amphoteric compounds almost correlated with their in vivo gastrointestinal prokinetic activities. This result suggested that 5- $\mathrm{HT}_{4}$ agonist activities of amphoteric compounds could contribute to their in vivo gastrointestinal prokinetic effects. Compound 19, however, exhibited excellent in vivo gastrointestinal prokinetic activity after intravenous administration in dogs in spite of weaker $5-\mathrm{HT}_{4}$ agonist activity than $\mathbf{1 b}$ $\left(\mathrm{pEC}_{50}=7.26\right){ }^{15)}$ Therefore, it was considered that other mechanisms contributed to the gastrointestinal activity of $\mathbf{1 9}$.

Examination of Prodrugs of Compound 19 As described above, compound 19, with an amphoteric monocyclic side chain, was selected as a candidate for a novel gastrointestinal prokinetics. Unfortunately, 19 showed only weak gastrointestinal activity by oral administration in further evaluation. It seemed that poor oral absorption of $\mathbf{1 9}$ was attributed to its low lipophilicity. On the other hand, the ethyl ester (13), its synthetic precursor, had potent gastrointestinal activity after oral administration, but an undesired emetic side effect was observed. We therefore set about examining the other various ester prodrugs of $\mathbf{1 9}$.

We tested for the gastrointestinal prokinetic and emetic action as well as the physicochemical and metabolic stability of the prodrugs. Their results were summarized in Table 11.

Among the double ester type of prodrugs (57-60), 58 showed the best pharmacological effect, but its physicochem-

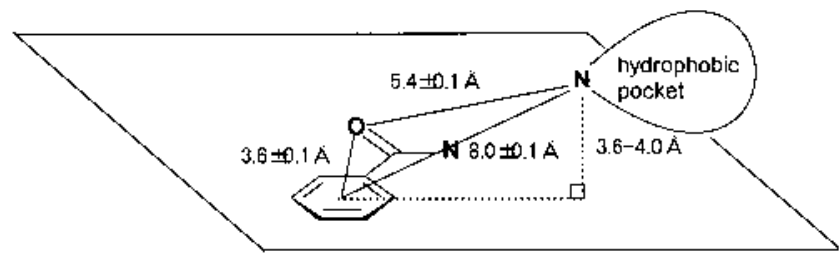

Fig. 2. 5- $\mathrm{HT}_{4}$ Pharmacophore Model

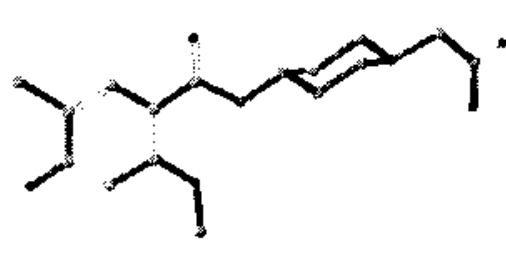

19

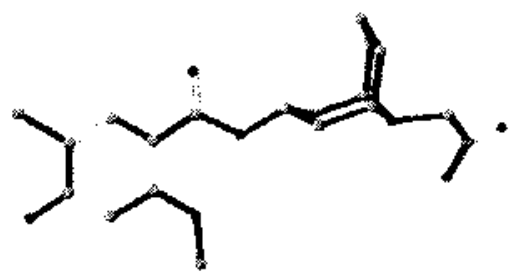

$32 b$

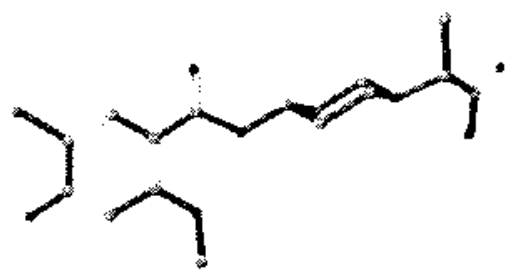

24

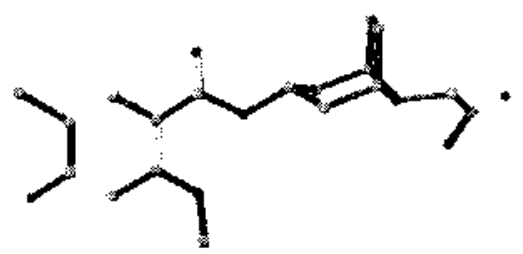

32c

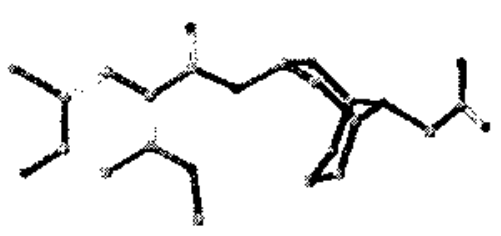

32a

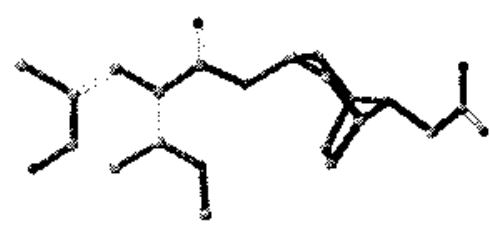

38

Fig. 3. Presumed Active Conformation of Compounds 19, 24, 32a $-\mathbf{c}, \mathbf{3 8}$ Calculated by the Molecular Modeling Program CAChe (Version 4.1.1) 
Table 10. Energy and Structural Parameters of the Conformations and 5- $\mathrm{HT}_{4}$ Agonist Activity

\begin{tabular}{|c|c|c|c|c|c|c|c|c|c|c|c|}
\hline Compd. & $\begin{array}{c}\text { Energy } \\
(\mathrm{kcal} / \mathrm{mol})\end{array}$ & $\begin{array}{c}\mathrm{E}^{a)} \\
(\mathrm{kcal} / \mathrm{mol})\end{array}$ & $\tau^{b)}$ & $\theta^{b)}$ & $\varpi^{b)}$ & $\psi^{b)}$ & $\operatorname{Ar}-\mathrm{N}(\AA)^{c)}$ & $\mathrm{Ar}-\mathrm{O}(\AA)^{d)}$ & $\mathrm{O}-\mathrm{N}(\AA)^{e)}$ & $h(\AA)^{f)}$ & $\begin{array}{c}\text { 5- } \mathrm{HT}_{4} \text { agonist activity } \\
\left(\mathrm{pEC}_{50}\right)\end{array}$ \\
\hline 19 & -10.79 & 0.29 & -148.9 & 89.7 & 167.3 & 142.9 & 7.93 & 3.51 & 5.47 & 1.49 & 6.11 \\
\hline 24 & -7.56 & 0.03 & -146.8 & 108.8 & 164.9 & 141.6 & 7.93 & 3.51 & 5.56 & 1.54 & 5.64 \\
\hline $32 a$ & 7.87 & 0.06 & -143.0 & -127.7 & 65.3 & -145.3 & 7.57 & 3.50 & 5.75 & 2.20 & 5.13 \\
\hline $32 b$ & 3.88 & 0.04 & -148.1 & 108.4 & 164.9 & 149.8 & 7.83 & 3.51 & 5.65 & 2.02 & 4.62 \\
\hline $32 \mathrm{c}$ & 2.50 & 0.01 & -146.5 & 111.8 & 175.5 & 150.2 & 7.82 & 3.50 & 5.69 & 1.72 & 5.40 \\
\hline \multirow[t]{2}{*}{38} & 4.61 & 0.16 & -145.5 & -122.8 & 69.9 & -149.3 & 7.48 & 3.50 & 5.75 & 1.79 & 5.32 \\
\hline & \multicolumn{6}{|c|}{ Pharmacophore model } & $8.0 \pm 0.1$ & $3.6 \pm 0.1$ & $5.4 \pm 0.1$ & $3.6-4.0$ & - \\
\hline
\end{tabular}

a) Increment of energy with respect to the lowest energy conformation. b) Torsion angle $\left({ }^{\circ}\right)$ defined in Fig. $\left.1 . \quad c\right)$ Distance between the centroid of the benzene ring and the basic nitrogen of the amine. d) Distance between the centroid of the benzene ring and the oxygen of the carboxyl group. $e$ ) Distance between the oxygen of the carboxyl group and the basic nitrogen of the amine. $f$ ) Deviation of the basic nitrogen with respect to the benzene ring.

Table 11. Pharmacological Data for Prodrugs $(\mathbf{1 3}, \mathbf{4 4}-\mathbf{6 0})$

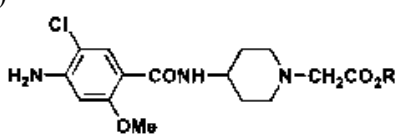

\begin{tabular}{|c|c|c|c|c|c|c|}
\hline \multirow[b]{2}{*}{ Compd. } & \multirow[b]{2}{*}{$\mathrm{R}$} & \multirow{2}{*}{$\begin{array}{l}\text { Gastric antrum }^{a)} \\
(1 \mathrm{mg} / \mathrm{kg}, \text { i.d. })\end{array}$} & \multirow{2}{*}{$\begin{array}{l}\text { Ascending colon }{ }^{b)} \\
(1 \mathrm{mg} / \mathrm{kg}, \text { i.d. })\end{array}$} & \multirow{2}{*}{$\begin{array}{c}\text { Vomiting in ferrets } \\
(10 \mathrm{mg} / \mathrm{kg}, \text { p.o. }) \\
\text { Response (\%) }\end{array}$} & \multicolumn{2}{|c|}{ Stability } \\
\hline & & & & & $\begin{array}{c}\text { Physicochemical }^{c)} \\
\text { residual } \%\end{array}$ & $\begin{array}{l}\text { Metabolic }^{d)} \\
\text { residual \% }\end{array}$ \\
\hline 13 & $\mathrm{Et}$ & ++ & 100 & 100 & 99 & 61 \\
\hline 44 & $\mathrm{Me}$ & ++ & 100 & 75 & 97 & 69 \\
\hline 45 & $n-\operatorname{Pr}$ & ++ & 80 & 25 & 97 & 49 \\
\hline 46 & $n-\mathrm{Bu}$ & ++ & 100 & 0 & 97 & 22 \\
\hline 47 & $n$-Pentyl & ++ & 80 & 0 & 98 & 2 \\
\hline 48 & $n$-Hex & ++ & 80 & 13 & 99 & 6 \\
\hline 49 & iso-Pr & ++ & 80 & 50 & 98 & 80 \\
\hline 50 & iso- $\mathrm{Bu}$ & ++ & 100 & 13 & $\mathrm{NT}^{e)}$ & 33 \\
\hline 51 & iso-Pentyl & ++ & 60 & 0 & 100 & 7 \\
\hline 52 & $\mathrm{CH}_{2} \mathrm{CH}_{2} \mathrm{OMe}$ & ++ & 100 & 0 & 96 & 70 \\
\hline 53 & Benzyl & ++ & 40 & 0 & 100 & 30 \\
\hline 54 & $\mathrm{CH}_{2} \mathrm{COMe}$ & + & 60 & 0 & 96 & $\mathrm{ND}^{f)}$ \\
\hline 55 & $\mathrm{CH}_{2} \mathrm{CO}_{2} \mathrm{Et}$ & ++ & 60 & 0 & 96 & 25 \\
\hline 56 & $\mathrm{CH}_{2} \mathrm{CONMe}_{2}$ & + & 40 & 0 & 92 & 97 \\
\hline 57 & & ++ & 80 & 0 & 82 & $\mathrm{ND}^{f}$ \\
\hline 58 & & ++ & 100 & 0 & 73 & $\mathrm{ND}^{f}$ \\
\hline 59 & & ++ & 40 & 0 & 85 & $\mathrm{ND}^{f)}$ \\
\hline 60 & & ++ & 60 & 0 & 84 & 7 \\
\hline
\end{tabular}

$a, b)$ See footnote $a$ and $b$ in Table 5. c) Physicochemical stability in buffer solution (pH 6.8). $d$ ) In vitro metabolic stability with human liver S9. e) Not tested. f) Not detected.

ical stability was not so good. Although benzyl ester (53) and alkyl esters, having functional groups (54-56), showed no emetic action, they had only moderate gastrointestinal prokinetic action. Methoxyethyl ester (52) showed good pharmacological actions but it was expected to be tolerant to hydrolysis. Among straight or branched alkyl esters (44-51), $n$ butyl (46) and $n$-pentyl (47) esters were preferable in terms of pharmacological and pharmacokinetic profiles. We selected the $n$-butyl prodrug (46), which exhibited the most potent gastrointestinal prokinetic activity, as a developing candidate.

Compound 46 also did not show the emetic side effect after oral administration in dogs. After oral administration of $46(10 \mathrm{mg} / \mathrm{kg})$ in rats, only 19 was detected in plasma. Accordingly, $\mathbf{4 6}$ was expected to exhibit excellent gastrointesti- nal prokinetic activity without significant CNS or emetic side effects.

\section{Conclusion}

1) The combination of amphoteric-ionization and cyclization of the terminal amine moiety of 1a caused an increase in gastro- and colon-prokinetic activities and a decrease in dopamine $\mathrm{D}_{2}$ receptor affinity. This combination seemed to be an effective approach to a selective gastrointestinal prokinetic activity devoid of other pharmacological activity such as CNS side effects, and also to generating marvelous colon-prokinetic activity.

2) Amphoteric-ionization was also effective for reducing the penetration into the brain.

3) $\mathrm{The} 5-\mathrm{HT}_{4}$ receptor agonist activity of $\mathbf{1 9}$ was consid- 
ered to participate partially in the gastrointestinal prokinetic effect.

4) According to our conformational analyses, the $\alpha$ methyl group in $\mathbf{2 4}$ and the alkylene-bridged chain in exo-bicyclic compounds $(\mathbf{3 2 b}, \mathbf{3 2 c})$ were found to be located at the same side of their amide carbonyl groups. These conformations might disturb the interaction in the binding mode between the ligand and $5-\mathrm{HT}_{4}$ receptor, leading to their lower gastrointestinal activity.

5) The $n$-butyl ester (46) of $\mathbf{1 9}$ was found to improve oral availability compared to $\mathbf{1 9}$, without an emetic side effect.

Further studies of the candidate, the ester 46 (Code No: AU-224), as a new gastrointestinal prokinetic agent for preclinical evaluation, is now in progress, and the mechanism for the active metabolite $\mathbf{1 9}$ is also being examined in detail.

\section{Experimental}

Chemistry All melting points were measured on a Yanagimoto melting point apparatus and are uncorrected. Spectral data were obtained using the following apparatus: ${ }^{1} \mathrm{H}-\mathrm{NMR}$ spectra with JEOL FX-90Q (90 MHz), JEOL EX-270 $(270 \mathrm{MHz})$ and JEOL A-500 (500 MHz) spectrometers; mass spectra (MS) with JEOL JMS-DX 300 mass spectrometer; IR spectra with Hitachi 270-30 spectrometer. Chemical shifts are expressed as $\delta(\mathrm{ppm})$ values with tetramethylsilane (TMS) as an internal standard. Column chromatography was carried out with Kieselgel 60 (Merck) or Aluminium oxide 90 (Merck). Elemental analyses were performed using Yanagimoto MT-3 and MT-5 elemental analysis apparatus, and analytical results were within $\pm 0.4 \%$ of theoretical values. TLC was conducted on a $0.25 \mathrm{~mm}$ pre-coated silica gel plate $\left(60 \mathrm{~F}_{254}\right.$, Merck), and spots were detected by inspection under short $(254 \mathrm{~nm})$ wavelength UV light, or by the colors developed with iodine. Organic extracts were dried over anhydrous $\mathrm{Na}_{2} \mathrm{SO}_{4}$. The solvent was evaporated under reduced pressure.

The following known intermediates and reference compounds were prepared essentially according to the literature: 4-amino-5-chloro- $N$-[2-(diethylamino)ethyl]-2-methoxybenzamide (metoclopramide 1a), ${ }^{6}$ cis-4-amino-5chloro- $N$-[1-[3-(4-fluorophenoxy)propyl]-3-methoxy-4-piperidyl]-2methoxybenzamide (cisapride 1b), ${ }^{4}$ 4-acetylamino-2-methoxybenzoic acid (25), ${ }^{6}$ endo- or exo-3-amino-9-benzyl-9-azabicyclo[3.3.1]nonane (26a, b), ${ }^{7}$ exo-3-amino-8-benzyl-8-azabicyclo[3.2.1] octane (26c), ${ }^{7}$ 1-methyl- $1 H$-indazole-3-carbonyl chloride $(\mathbf{3 9 d}),{ }^{8} 1 \mathrm{H}$-indole-3-carbonyl chloride $(\mathbf{3 9 e}),{ }^{9)} 1$ methyl-1H-indole-3-carbonyl chloride (39f), ${ }^{9)}$ 4-amino-5-chloro- $N$-(1methyl-4-piperidyl)-2-methoxybenzamide $(\mathbf{6 1}),{ }^{11)}$ endo-4-amino-5-chloro-2methoxy- $N$-(9-methyl-9-azabicyclo[3.3.1]nonan-3-yl)benzamide (62), ${ }^{7}$ exo4-amino-5-chloro-2-methoxy- $N$-(9-methyl-9-azabicyclo[3.3.1]nonan-3yl)benzamide (63), ${ }^{7}$ exo-4-amino-5-chloro-2-methoxy- $N$-(8-methyl-8-azabicyclo[3.2.1] oct-3-yl)benzamide $(64){ }^{7}{ }^{7}$ endo-4-amino-5-chloro-2-methoxy$N$-(8-methyl-8-azabicyclo[3.2.1] oct-3-yl)benzamide (BRL24682; 65), ${ }^{7)}$ endo-1-methyl- $N$-(9-methyl-9-azabicyclo[3.3.1]non-3-yl)-1 $H$-indazole-3carboxamide (66), ${ }^{8}$ endo- $N$-(9-methyl-9-azabicyclo[3.3.1]non-3-yl)indole3-carboxamide (67), ${ }^{7)}$ endo-1-methyl- $N$-(9-methyl-9-azabicyclo[3.3.1]non3-yl)indole-3-carboxamide (68). ${ }^{7}$

Method A. N-(1-Benzyl-4-piperidyl)trifluoroacetamide (6) A solution of 4-amino-1-benzylpiperidine $\mathbf{5}(25.0 \mathrm{~g}, 131 \mathrm{mmol})$ and trifluoroacetic anhydride $(20.4 \mathrm{ml}, 147 \mathrm{mmol})$ in $\mathrm{CH}_{2} \mathrm{Cl}_{2}(100 \mathrm{ml})$ was stirred at room temperature for $30 \mathrm{~min}$. The reaction mixture was concentrated and saturated aqueous $\mathrm{NaHCO}_{3}$ was added to the residue. The mixture was extracted with $\mathrm{CH}_{2} \mathrm{Cl}_{2}$. The extract was dried and evaporated. The resulting residue was converted to the hydrochloride in the usual way to give the hydrochloride $(41.6 \mathrm{~g}, 98 \%)$ of $\mathbf{6}$ as a colorless crystal, which was recrystallized from AcOEt to give colorless needles, mp $205-207^{\circ} \mathrm{C}$. Anal. Calcd For $\mathrm{C}_{14} \mathrm{H}_{17} \mathrm{~F}_{3} \mathrm{~N}_{2} \mathrm{O} \cdot \mathrm{HCl}: \mathrm{C}, 52.10 ; \mathrm{H}, 5.62 ; \mathrm{N}, 8.68$. Found: $\mathrm{C}, 51.89 ; \mathrm{H}, 5.53 ; \mathrm{N}$, 8.67. MS $m / z: 286\left(\mathrm{M}^{+}\right)$. IR $v$ (liq) $\mathrm{cm}^{-1}: 1714 .{ }^{1} \mathrm{H}-\mathrm{NMR}$ (DMSO- $\left.d_{6}\right)$ : $1.25-2.65(10 \mathrm{H}, \mathrm{m}), 3.35(1 \mathrm{H}, \mathrm{br} \mathrm{s}), 3.55-3.95(2 \mathrm{H}, \mathrm{m}), 4.13(3 \mathrm{H}, \mathrm{s})$, $4.25-4.80(1 \mathrm{H}, \mathrm{m}), 7.15-7.80(3 \mathrm{H}, \mathrm{m}), 8.05-8.35(1 \mathrm{H}, \mathrm{m}), 8.40-9.40$ $(1 \mathrm{H}, \mathrm{m})$.

$N$-(4-Piperidyl)trifluoroacetamide (7) A mixture of the hydrochloride of $6(40.0 \mathrm{~g}, 124 \mathrm{mmol}), 10 \% \mathrm{Pd}-\mathrm{C}(5.0 \mathrm{~g})$ and $\mathrm{H}_{2} \mathrm{O}(50 \mathrm{ml})$ in $\mathrm{MeOH}$ $\left(200 \mathrm{ml}\right.$ ) was stirred at $35^{\circ} \mathrm{C}$ and $2 \mathrm{~atm}$ of $\mathrm{H}_{2}$ for $3 \mathrm{~h}$. The catalyst was removed by filtration and the filtrate was evaporated. The resulting residue was recrystallized from $\mathrm{MeOH}$ to afford the hydrochloride (20.8 g, $72 \%$ ) of 7 as a colorless crystal, mp 236-240 ${ }^{\circ} \mathrm{C}$. Anal. Calcd For $\mathrm{C}_{7} \mathrm{H}_{11} \mathrm{~F}_{3} \mathrm{~N}_{2} \mathrm{O} \cdot \mathrm{HCl}$ : C, 36.14; H, 5.20; N, 12.04. Found: C, 36.01; H, 5.12; N, 12.25. MS m/z: 196 $\left(\mathrm{M}^{+}\right)$. IR $v$ (liq) $\mathrm{cm}^{-1}: 1720 .{ }^{1} \mathrm{H}-\mathrm{NMR}$ (DMSO- $\left.d_{6}\right): 1.75-1.95(2 \mathrm{H}, \mathrm{m})$, $2.05-2.20(2 \mathrm{H}, \mathrm{m}), 3.05-3.20(2 \mathrm{H}, \mathrm{m}), 3.40-3.55(2 \mathrm{H}, \mathrm{m}), 3.95-4.15$ $(1 \mathrm{H}, \mathrm{m})$.

$\mathrm{N}$-(1-Trityl-4-piperidyl)trifluoroacetamide (8) A mixture of 7 (186.4 g, $950 \mathrm{mmol})$, trityl chloride $(264.8 \mathrm{~g}, 950 \mathrm{mmol})$ and $\mathrm{Et}_{3} \mathrm{~N}(145.7 \mathrm{ml}$, $1.05 \mathrm{~mol}$ ) in $\mathrm{CH}_{2} \mathrm{Cl}_{2}$ was stirred at room temperature for $3 \mathrm{~h}$. Water $(1000 \mathrm{ml})$ was poured into the reaction mixture and the mixture was extracted with $\mathrm{CH}_{2} \mathrm{Cl}_{2}$. The extracts were evaporated and the resulting residue was washed with diisopropyl ether (iso- $\mathrm{Pr}_{2} \mathrm{O}$ ) to afford $303.5 \mathrm{~g}(73 \%)$ of 8 as a colorless crystal, which was used for the next step without further purification. MS $m / z$ : $438\left(\mathrm{M}^{+}\right)$. IR $v(\mathrm{KBr}) \mathrm{cm}^{-1}: 1716,1696 .{ }^{1} \mathrm{H}-\mathrm{NMR}\left(\mathrm{CDCl}_{3}\right)$ : $1.35-1.60(2 \mathrm{H}, \mathrm{m}), 1.70-1.80(2 \mathrm{H}, \mathrm{m}), 1.90-2.05(2 \mathrm{H}, \mathrm{m}), 2.95-3.20$ $(2 \mathrm{H}, \mathrm{m}), 3.60-3.70(1 \mathrm{H}, \mathrm{m}), 6.05-6.15(1 \mathrm{H}, \mathrm{m}), 7.15-7.50(15 \mathrm{H}, \mathrm{m})$.

4-Amino-1-tritylpiperidine (9) A mixture of $8(206.4 \mathrm{~g}, 471 \mathrm{mmol})$, $\mathrm{KOH}(62.13 \mathrm{~g}, 941 \mathrm{mmol})$ in $\mathrm{H}_{2} \mathrm{O}$ (1 1 ) and EtOH (1 l) was refluxed for $2.5 \mathrm{~h}$. After cooling, the resulting precipitate was collected by filtration and washed successively with water and $n$-hexane, to afford $151.1 \mathrm{~g}(94 \%)$ of 9 as a colorless crystal, which was used for the next step without further purification. MS $m / z: 342\left(\mathrm{M}^{+}\right)$. IR $v(\mathrm{KBr}) \mathrm{cm}^{-1}: 1596 .{ }^{1} \mathrm{H}-\mathrm{NMR}\left(\mathrm{CDCl}_{3}\right)$ : $1.30-1.95(6 \mathrm{H}, \mathrm{m}), 2.40-2.60(1 \mathrm{H}, \mathrm{m}), 2.85-3.20(2 \mathrm{H}, \mathrm{m}), 7.10-7.55$ $(15 \mathrm{H}, \mathrm{m})$.

4-Amino-5-chloro-2-methoxy- $N$-(1-trityl-4-piperidyl)benzamide (11) A mixture of $10(16.4 \mathrm{~g}, 81.3 \mathrm{mmol}), \mathrm{Et}_{3} \mathrm{~N}(13.6 \mathrm{ml}, 97.7 \mathrm{mmol})$ and $\mathrm{ClCO}_{2} \mathrm{Et}(8.55 \mathrm{ml}, 89.9 \mathrm{mmol})$ in anhydrous tetrahydrofuran (THF, $\left.330 \mathrm{ml}\right)$ was stirred under ice cooling. After $2 \mathrm{~h}, 9(30.6 \mathrm{~g}, 89.3 \mathrm{mmol})$ was added dropwise to the mixture and stirred at room temperature for $20 \mathrm{~h}$. The insoluble substance was filtered off and the filtrate was evaporated. The resulting residue was dissolved in $\mathrm{CH}_{2} \mathrm{Cl}_{2}$. The $\mathrm{CH}_{2} \mathrm{Cl}_{2}$ solution was washed with water, dried and evaporated. The residue was washed with $n$-hexane to afford $39.4 \mathrm{~g} \mathrm{(92 \% )}$ of $\mathbf{1 1}$ as a colorless crystal, which was used for the next step without further purification. MS $m / z: 525,527\left(3: 1, \mathrm{M}^{+}\right)$. IR $v(\mathrm{KBr})$ $\mathrm{cm}^{-1}: 1646,1624 .{ }^{1} \mathrm{H}-\mathrm{NMR}\left(\mathrm{CDCl}_{3}\right): 1.55-1.80(2 \mathrm{H}, \mathrm{m}), 1.90-2.20(2 \mathrm{H}$, $\mathrm{m}), 2.70-3.40(2 \mathrm{H}, \mathrm{m}), 3.55-4.10(3 \mathrm{H}, \mathrm{m}), 4.33(2 \mathrm{H}, \mathrm{br} \mathrm{s}), 6.25(1 \mathrm{H}, \mathrm{s})$, $7.05-7.55(15 \mathrm{H}, \mathrm{m}), 7.67(1 \mathrm{H}, \mathrm{brs}), 8.06(1 \mathrm{H}, \mathrm{s})$.

4-Amino-5-chloro-2-methoxy- $N$-(4-piperidyl)benzamide (12) A mixture of $11(39.4 \mathrm{~g}, 74.9 \mathrm{mmol})$ and concentrated $\mathrm{HCl}(10 \mathrm{ml})$ in acetone $(600 \mathrm{ml})$ was refluxed for $40 \mathrm{~min}$. After cooling, the resulting precipitate was collected by filtration and washed with acetone to afford the hydrochloride $(25.8 \mathrm{~g}, 78 \%)$ of $\mathbf{1 2}^{5)}$ as a colorless crystal, which was recrystallized from EtOH to afford colorless crystals, mp $214-217^{\circ} \mathrm{C}$. Anal. Calcd for $\mathrm{C}_{13} \mathrm{H}_{18} \mathrm{ClN}_{3} \mathrm{O}_{2} \cdot \mathrm{HCl} \cdot 1 / 2 \mathrm{H}_{2} \mathrm{O}: \mathrm{C}, 47.43 ; \mathrm{H}, 6.12 ; \mathrm{N}, 12.76$. Found: $\mathrm{C}, 47.64$; $\mathrm{H}, 6.39 ; \mathrm{N}, 12.97$. MS $m / z: 283,285\left(3: 1, \mathrm{M}^{+}\right)$. IR $v(\mathrm{KBr}) \mathrm{cm}^{-1}: 2948$, 2812, 1640. ${ }^{1} \mathrm{H}-\mathrm{NMR}$ (DMSO- $\left.d_{6}\right): 1.60-1.85(2 \mathrm{H}, \mathrm{m}), 1.90-2.15(2 \mathrm{H}, \mathrm{m})$, $2.85-3.10(2 \mathrm{H}, \mathrm{m}), 3.10-3.35(2 \mathrm{H}, \mathrm{m}), 3.83(3 \mathrm{H}, \mathrm{s}), 3.85-4.10(1 \mathrm{H}, \mathrm{m})$, $6.35(1 \mathrm{H}, \mathrm{s}), 7.62(1 \mathrm{H}, \mathrm{s}), 7.65-7.80(1 \mathrm{H}, \mathrm{m})$.

Ethyl 4-[(4-Amino-5-chloro-2-methoxybenzoyl)amino]-1-piperidineacetate (13) A mixture of the hydrochloride of $\mathbf{1 2}(3.20 \mathrm{~g}, 9.91 \mathrm{mmol})$, ethyl bromoacetate $(1.22 \mathrm{ml}, 11.0 \mathrm{mmol})$ and $\mathrm{K}_{2} \mathrm{CO}_{3}(3.04 \mathrm{~g}, 22.0 \mathrm{mmol})$ in DMF $\left(32 \mathrm{ml}\right.$ ) was stirred at $60^{\circ} \mathrm{C}$ for $2.5 \mathrm{~h}$. After evaporation of the solvent, water was added to the residue and extracted with $\mathrm{CH}_{2} \mathrm{Cl}_{2}$. The organic layer was washed with water, dried and evaporated to afford yellow oily residue. The residue was converted to the hydrochloride in the usual manner to afford the hydrochloride (3.31 g, 73\%) of $\mathbf{1 3}$ as a pale yellow crystal, which was recrystallized from EtOH to afford colorless flakes, $\mathrm{mp} 196.5-198.5^{\circ} \mathrm{C}$. Anal. Calcd for $\mathrm{C}_{17} \mathrm{H}_{24} \mathrm{ClN}_{3} \mathrm{O}_{4} \cdot \mathrm{HCl}: \mathrm{C}, 50.25 ; \mathrm{H}, 6.20 ; \mathrm{N}, 10.34$. Found: $\mathrm{C}$, 49.98; H, 6.23; N, 10.36. MS m/z: 369, $371\left(3: 1, \mathrm{M}^{+}\right)$. IR $v(\mathrm{KBr}) \mathrm{cm}^{-1}$ : $1758,1650 .{ }^{1} \mathrm{H}-\mathrm{NMR}$ (DMSO- $\left.d_{6}\right): 1.26(3 \mathrm{H}, \mathrm{t}, J=7.0 \mathrm{~Hz}), 1.75-2.20(4 \mathrm{H}$, m), $3.05-3.70(4 \mathrm{H}, \mathrm{m}), 3.75-4.20(1 \mathrm{H}, \mathrm{m}), 3.84(3 \mathrm{H}, \mathrm{s}), 4.17(2 \mathrm{H}, \mathrm{s}), 4.24$ $(2 \mathrm{H}, \mathrm{q}, J=7.0 \mathrm{~Hz}), 6.54(1 \mathrm{H}, \mathrm{s}), 7.63(1 \mathrm{H}, \mathrm{s}), 7.74(1 \mathrm{H}, \mathrm{br} \mathrm{s})$.

Compounds 15-18 were prepared in a manner similar to that described above and their physicochemical data were summarized in Table 1.

Ethyl 4-[(4-Amino-5-chloro-2-methoxybenzoyl)amino]-1-piperidinepropionate (14) A mixture of $\mathbf{1 2}(2.79 \mathrm{~g}, 9.80 \mathrm{mmol})$ and ethyl acrylate $(1.35 \mathrm{ml}, 12.5 \mathrm{mmol})$ in EtOH $(28 \mathrm{ml})$ was refluxed for $4 \mathrm{~h}$. The reaction mixture was concentrated and the residue was washed with iso- $\operatorname{Pr}_{2} \mathrm{O}$ to afford pale yellow crystals $(3.34 \mathrm{~g}, 87 \%)$, which were recrystallized from a mixture of acetone and $\mathrm{Et}_{2} \mathrm{O}$ to give colorless needles, mp $116-117.5^{\circ} \mathrm{C}$. Anal. Calcd for $\mathrm{C}_{18} \mathrm{H}_{26} \mathrm{ClN}_{3} \mathrm{O}_{4}: \mathrm{C}, 56.32 ; \mathrm{H}, 6.83 ; \mathrm{N}, 10.95$. Found: $\mathrm{C}$, 56.28; H, 6.78; N, 10.87. MS $m / z: 383,385\left(3: 1, \mathrm{M}^{+}\right)$. IR $v(\mathrm{KBr}) \mathrm{cm}^{-1}$ : $1730,1628 .{ }^{1} \mathrm{H}-\mathrm{NMR}$ (DMSO- $\left.d_{6}\right): 1.18(3 \mathrm{H}, \mathrm{t}, J=7.0 \mathrm{~Hz}), 1.40-1.60(2 \mathrm{H}$, m), $1.70-1.90(2 \mathrm{H}, \mathrm{m}), 2.05-2.15(2 \mathrm{H}, \mathrm{m}), 2.35-2.80(6 \mathrm{H}, \mathrm{m}), 3.65-$ 
$3.85(1 \mathrm{H}, \mathrm{m}), 3.84(3 \mathrm{H}, \mathrm{s}), 4.06(2 \mathrm{H}, \mathrm{q}, J=7.0 \mathrm{~Hz}), 5.70-5.85(2 \mathrm{H}, \mathrm{br} \mathrm{s})$, $6.49(1 \mathrm{H}, \mathrm{s}), 7.60-7.75(1 \mathrm{H}, \mathrm{m}), 7.66(1 \mathrm{H}, \mathrm{s})$.

4-[(4-Amino-5-chloro-2-methoxybenzoyl)amino]-1-piperidineacetic Acid (19) A mixture of the hydrochloride of 13 (2.23 g, $5.49 \mathrm{mmol})$ and $2 \mathrm{~N}$ aqueous $\mathrm{NaOH}$ solution $(9.86 \mathrm{ml})$ in $\mathrm{MeOH}(22 \mathrm{ml})$ was refluxed for $1 \mathrm{~h}$. The reaction mixture was concentrated and the resulting residue was dissolved in a small amount of water. The solution was adjusted to $\mathrm{pH} 2$ with $10 \% \mathrm{HCl}$. The resulting precipitate was collected by filtration and washed with water to afford the hydrochloride $(1.47 \mathrm{~g}, 78 \%)$ of $\mathbf{1 9}$ as a pale brown crystal, which was recrystallized from water to afford pale yellow pillars, $\mathrm{mp}$ $248-251{ }^{\circ} \mathrm{C}$ (dec.). Anal. Calcd for $\mathrm{C}_{15} \mathrm{H}_{20} \mathrm{ClN}_{3} \mathrm{O}_{4} \cdot \mathrm{HCl} \cdot 1 / 4 \mathrm{H}_{2} \mathrm{O}: \mathrm{C}, 47.07$; $\mathrm{H}, 5.66$; N 10.98. Found: C, 47.34; H, 5.58; N, 11.08. MS $m / z$ : 341, 343 $\left(3: 1, \mathrm{M}^{+}\right)$. IR $v(\mathrm{KBr}) \mathrm{cm}^{-1}: 1734,1628 .{ }^{1} \mathrm{H}-\mathrm{NMR}\left(\mathrm{DMSO}-d_{6}\right): 1.75-2.20$ $(4 \mathrm{H}, \mathrm{m}), 3.05-3.35(2 \mathrm{H}, \mathrm{m}), 3.35-3.60(2 \mathrm{H}, \mathrm{m}), 3.85(3 \mathrm{H}, \mathrm{s}), 3.85-4.10$ $(1 \mathrm{H}, \mathrm{m}), 3.98(2 \mathrm{H}, \mathrm{s}), 6.55(1 \mathrm{H}, \mathrm{s}), 7.63(1 \mathrm{H}, \mathrm{s}), 7.65-7.80(1 \mathrm{H}, \mathrm{m})$.

Compounds 20-24 were prepared in a manner similar to that described above and their physicochemical data were summarized in Table 1.

Method B. endo-4-Acetylamino- $N$-(9-benzyl-9-azabicyclo[3.3.1]non3-yl)-2-methoxybenzamide (27a) A mixture of 4-acetylamino-2-methoxybenzoic acid $25(11.0 \mathrm{~g}, 52.6 \mathrm{mmol}), \mathrm{ClCO}_{2} \mathrm{Et}(5.28 \mathrm{ml}, 55.2 \mathrm{mmol})$ and $\mathrm{Et}_{3} \mathrm{~N}(8.43 \mathrm{ml}, 60.5 \mathrm{mmol})$ in THF $(210 \mathrm{ml})$ was stirred for $1.5 \mathrm{~h}$ at room temperature. Under ice-cooling, endo-3-amino-9-benzyl-9-azabicyclo[3.3.1]nonane $26 \mathrm{a}(12.7 \mathrm{~g}, 55.2 \mathrm{mmol})$ was added dropwise to the mixture and the resulting mixture was stirred at room temperature for $2.5 \mathrm{~d}$. The reaction mixture was concentrated and water was added to the residue. The solution was adjusted to $\mathrm{pH} 9$ with $10 \%$ aqueous $\mathrm{K}_{2} \mathrm{CO}_{3}$. The resulting precipitate was collected by filtration, washed successively with water and ethanol and dried to afford $15.7 \mathrm{~g} \mathrm{(71 \% )} \mathrm{of} \mathbf{2 7 a}$ as a colorless crystal, which was used in the next step without further purification. MS $m / z: 421\left(\mathrm{M}^{+}\right)$. IR $v(\mathrm{KBr})$ $\mathrm{cm}^{-1}: 1690,1624 .{ }^{1} \mathrm{H}-\mathrm{NMR}$ (DMSO- $\left.d_{6}\right): 0.90-1.15(2 \mathrm{H}, \mathrm{m}), 1.25-1.60$ $(3 \mathrm{H}, \mathrm{m}), 1.80-2.40(5 \mathrm{H}, \mathrm{m}), 2.06(3 \mathrm{H}, \mathrm{s}), 2.95-3.15(2 \mathrm{H}, \mathrm{m}), 3.81(2 \mathrm{H}$, s), $3.86(3 \mathrm{H}, \mathrm{s}), 4.25-4.50(1 \mathrm{H}, \mathrm{m}), 7.10-7.45(5 \mathrm{H}, \mathrm{m}), 7.18(1 \mathrm{H}, \mathrm{dd}$, $J=8.5,2 \mathrm{~Hz}), 7.49(1 \mathrm{H}, \mathrm{d}, J=2 \mathrm{~Hz}), 7.60-7.80(1 \mathrm{H}, \mathrm{m}), 7.72(1 \mathrm{H}, \mathrm{d}$, $J=8.5 \mathrm{~Hz}), 10.04(1 \mathrm{H}, \mathrm{s})$.

Compounds $\mathbf{2 7 b}, \mathbf{c}$ were prepared in a manner similar to that described above. 27b: MS $m / z$ : $421\left(\mathrm{M}^{+}\right)$. IR $v(\mathrm{KBr}) \mathrm{cm}^{-1}: 1692,1666 .{ }^{1} \mathrm{H}-\mathrm{NMR}$ $\left(\right.$ DMSO- $\left.d_{6}\right): 1.35-1.60(2 \mathrm{H}, \mathrm{m}), 1.55-2.15(8 \mathrm{H}, \mathrm{m}), 2.07(3 \mathrm{H}, \mathrm{s}), 2.75-$ $2.95(2 \mathrm{H}, \mathrm{m}), 3.83(2 \mathrm{H}, \mathrm{s}), 3.87(3 \mathrm{H}, \mathrm{s}), 4.55-4.85(1 \mathrm{H}, \mathrm{m}), 7.10-7.45$ $(5 \mathrm{H}, \mathrm{m}), 7.18(1 \mathrm{H}, \mathrm{dd}, J=8.5,1.5 \mathrm{~Hz}), 7.50(1 \mathrm{H}, \mathrm{d}, J=2 \mathrm{~Hz}), 7.60-7.75$ $(1 \mathrm{H}, \mathrm{m}), 7.70(1 \mathrm{H}, \mathrm{d}, J=8.5 \mathrm{~Hz}), 10.04(1 \mathrm{H}, \mathrm{s}) .27 \mathrm{c}: \mathrm{MS} m / z: 407\left(\mathrm{M}^{+}\right)$. IR $v(\mathrm{KBr}) \mathrm{cm}^{-1}: 1694,1630 .{ }^{1} \mathrm{H}-\mathrm{NMR}$ (DMSO- $\left.d_{6}\right): 1.50-1.85(6 \mathrm{H}, \mathrm{m})$, $1.90-2.15(2 \mathrm{H}, \mathrm{m}), 2.06(3 \mathrm{H}, \mathrm{s}), 3.05-3.35(2 \mathrm{H}, \mathrm{m}), 3.55(2 \mathrm{H}, \mathrm{s}), 3.85$ $(3 \mathrm{H}, \mathrm{s}), 4.05-4.30(1 \mathrm{H}, \mathrm{m}), 7.10-7.45(5 \mathrm{H}, \mathrm{m}), 7.17(1 \mathrm{H}, \mathrm{dd}, J=8.5$, $1.5 \mathrm{~Hz}), 7.48(1 \mathrm{H}, \mathrm{d}, J=1.5 \mathrm{~Hz}), 7.60-7.80(1 \mathrm{H}, \mathrm{m}), 7.70(1 \mathrm{H}, \mathrm{d}$, $J=8.5 \mathrm{~Hz}), 10.04(1 \mathrm{H}, \mathrm{s})$.

endo-4-Acetylamino- $\mathrm{N}$-(9-azabicyclo[3.3.1]non-3-yl)-2-methoxybenzamide (28a) A mixture of 27 a $(15.5 \mathrm{~g}, 36.8 \mathrm{mmol})$, acetic acid $(20 \mathrm{ml})$ and Pearlman's catalyst $(2.0 \mathrm{~g})$ in $\mathrm{MeOH}(180 \mathrm{ml})$ was stirred at room temperature and an atmospheric pressure of $\mathrm{H}_{2}$ for $1 \mathrm{~h}$. The catalyst was removed by filtration and the filtrate was evaporated. The resulting residue was dissolved in water and the solution was adjusted to $\mathrm{pH} 9$ with $10 \%$ aqueous $\mathrm{K}_{2} \mathrm{CO}_{3}$. The resulting precipitate was collected by filtration, washed with water and dried to give $11.7 \mathrm{~g}(95 \%)$ of $\mathbf{2 8 a}$ as a pale yellow crystal, which was recrystallized from 1,2-dichloroethane to afford colorless prisms, mp 196$200^{\circ} \mathrm{C}$. Anal. Calcd for $\mathrm{C}_{18} \mathrm{H}_{25} \mathrm{~N}_{3} \mathrm{O}_{3} \cdot 1 / 4 \mathrm{H}_{2} \mathrm{O}: \mathrm{C}, 64.36 ; \mathrm{H}, 7.65 ; \mathrm{N}, 12.51$. Found: C, 64.32; $\mathrm{H}, 7.53 ; \mathrm{N}, 12.47$. MS $m / z: 331\left(\mathrm{M}^{+}\right)$. IR $v(\mathrm{KBr}) \mathrm{cm}^{-1}$ : $1692,1634 .{ }^{1} \mathrm{H}-\mathrm{NMR}$ (DMSO- $\left.d_{6}\right): 1.10-1.70(7 \mathrm{H}, \mathrm{m}), 1.80-2.30(3 \mathrm{H}, \mathrm{m})$, $2.06(3 \mathrm{H}, \mathrm{s}), 3.00-3.40(2 \mathrm{H}, \mathrm{m}), 3.86(3 \mathrm{H}, \mathrm{s}), 3.95-4.20(1 \mathrm{H}, \mathrm{m}), 7.17$ $(1 \mathrm{H}, \mathrm{dd}, J=8.5,1.5 \mathrm{~Hz}), 7.48(1 \mathrm{H}, \mathrm{d}, J=1.5 \mathrm{~Hz}), 7.55-7.75(1 \mathrm{H}, \mathrm{m}), 7.72$ $(1 \mathrm{H}, \mathrm{d}, J=8.5 \mathrm{~Hz}), 10.04(1 \mathrm{H}, \mathrm{br} \mathrm{s})$.

Compounds $\mathbf{2 8 b}, \mathbf{c}$ were prepared in a manner similar to that described above and their physicochemical data were summarized in Table 2 .

Ethyl endo-3-[(4-Acetylamino-2-methoxybenzoyl)amino]-9-azabicyclo[3.3.1]nonane-9-acetate (29a) A mixture of 28a $(11.6 \mathrm{~g}, 34.5 \mathrm{mmol})$, ethyl bromoacetate $(4.60 \mathrm{ml}, 41.4 \mathrm{mmol})$ and $\mathrm{K}_{2} \mathrm{CO}_{3}(5.72 \mathrm{~g}, 41.4 \mathrm{mmol})$ in DMF $(75 \mathrm{ml})$ was stirred at $60^{\circ} \mathrm{C}$ for $2 \mathrm{~h}$. The reaction mixture was poured into water. The resulting precipitate was collected by filtration and washed with water to afford $13.4 \mathrm{~g}(91 \%)$ of $\mathbf{2 9 a}$ as a pale yellow crystal, which was recrystallized from benzene to give colorless prisms, $\mathrm{mp} 85-88^{\circ} \mathrm{C}$. Anal. Calcd for $\mathrm{C}_{22} \mathrm{H}_{31} \mathrm{~N}_{3} \mathrm{O}_{5} \cdot 1 / 2 \mathrm{H}_{2} \mathrm{O}: \mathrm{C}, 61.95 ; \mathrm{H}, 7.56 ; \mathrm{N}, 9.85$. Found: $\mathrm{C}, 61.85$; $\mathrm{H}, 7.55$; N, 9.86. MS $m / z$ : $417\left(\mathrm{M}^{+}\right)$. IR $v$ (liq) $\mathrm{cm}^{-1}: 1732,1694,1636 .{ }^{1} \mathrm{H}-$ NMR $\left(\mathrm{CDCl}_{3}\right): 1.00-1.65(4 \mathrm{H}, \mathrm{m}), 1.26(3 \mathrm{H}, \mathrm{t}, J=7 \mathrm{~Hz}), 1.75-2.15(2 \mathrm{H}$, $\mathrm{m}), 2.22(3 \mathrm{H}, \mathrm{s}), 2.40-2.65(2 \mathrm{H}, \mathrm{m}), 3.05-3.30(2 \mathrm{H}, \mathrm{m}), 3.47(2 \mathrm{H}, \mathrm{s}), 3.92$ $(3 \mathrm{H}, \mathrm{s}), 4.15(2 \mathrm{H}, \mathrm{q}, J=7 \mathrm{~Hz}), 4.35-4.60(1 \mathrm{H}, \mathrm{m}), 6.83(1 \mathrm{H}, \mathrm{dd}, J=8.5$,
$2 \mathrm{~Hz}), 7.65-7.80(1 \mathrm{H}, \mathrm{m}), 7.83(1 \mathrm{H}, \mathrm{d}, J=2 \mathrm{~Hz}), 8.04(1 \mathrm{H}, \mathrm{d}, J=8.5 \mathrm{~Hz})$, $8.77(1 \mathrm{H}, \mathrm{s})$

Compounds 29b,c were prepared in a manner similar to that described above and their physicochemical data were summarized in Table 2.

Ethyl endo-3-[(4-Acetylamino-5-chloro-2-methoxybenzoyl)amino]-9azabicyclo[3.3.1]nonnane-9-acetate (30a) The mixture of 29a $(13.0 \mathrm{~g}$, $31.1 \mathrm{mmol})$ and $\mathrm{SO}_{2} \mathrm{Cl}_{2}(3.42 \mathrm{ml}, 34.3 \mathrm{mmol})$ in $\mathrm{CH}_{2} \mathrm{Cl}_{2}(140 \mathrm{ml})$ was stirred at room temperature for $1.5 \mathrm{~h}$. The reaction mixture was basified with aqueous $\mathrm{NaHCO}_{3}$. The organic layer was dried and evaporated. The resulting residue was purified by column chromatography $\left[\mathrm{SiO}_{2}, \mathrm{CH}_{2} \mathrm{Cl}_{2}-\mathrm{MeOH}\right.$ $(50: 1)]$ to afford $11.4 \mathrm{~g}(81 \%)$ of $\mathbf{3 0 a}$ as a pale yellow amorphous solid. High resolution MS m/z: Calcd for $\mathrm{C}_{22} \mathrm{H}_{30} \mathrm{ClN}_{3} \mathrm{O}_{5}$ : 451.1874, 453.1844 . Found: 451.1859, 453.1853. MS $m / z: 451,453\left(\mathrm{M}^{+}, 3: 1\right)$. IR $v(\mathrm{KBr}) \mathrm{cm}^{-1}$ : 1750, 1646. ${ }^{1} \mathrm{H}-\mathrm{NMR}\left(\mathrm{CDCl}_{3}\right): 1.05-2.20(8 \mathrm{H}, \mathrm{m}), 1.28(3 \mathrm{H}, \mathrm{t}, J=7.5 \mathrm{~Hz})$, $2.28(3 \mathrm{H}, \mathrm{s}), 2.40-2.65(2 \mathrm{H}, \mathrm{m}), 3.10-3.35(2 \mathrm{H}, \mathrm{m}), 3.49(2 \mathrm{H}, \mathrm{s}), 3.98$ $(3 \mathrm{H}, \mathrm{s}), 4.17(2 \mathrm{H}, \mathrm{q}, J=7.5 \mathrm{~Hz}), 7.55-7.70(1 \mathrm{H}, \mathrm{m}), 7.80(1 \mathrm{H}, \mathrm{s}), 8.22(1 \mathrm{H}$, $\mathrm{s}), 8.32(1 \mathrm{H}, \mathrm{s})$.

Compounds $30 \mathbf{b}, \mathbf{c}$ were prepared in a manner similar to that described above and physicochemical data were summarized in Table 2.

Ethyl endo-3-[(4-Amino-5-chloro-2-methoxybenzoyl)amino]-9-azabicyclo[3.3.1]nonane-9-acetate (31a) A mixture of 30a $(11.0 \mathrm{~g}, 24.4 \mathrm{mmol})$ and $20 \%$ ethanolic hydrochloride $(66 \mathrm{ml})$ in $\mathrm{EtOH}(22 \mathrm{ml})$ was refluxed for $1 \mathrm{~h}$. The reaction mixture was evaporated and the resulting residue was dissolved in water. The solution was adjusted to $\mathrm{pH} 10$ with $\mathrm{K}_{2} \mathrm{CO}_{3}$. The resulting precipitate was collected by filtration and washed successively with water and iso- $\mathrm{Pr}_{2} \mathrm{O}$ to give $8.88 \mathrm{~g}(89 \%)$ of 31a as a pale brown crystal, which was recrystallized from EtOH to afford colorless needles, mp 163.5164.5 ${ }^{\circ} \mathrm{C}$. Anal. Calcd for $\mathrm{C}_{20} \mathrm{H}_{28} \mathrm{ClN}_{3} \mathrm{O}_{4}$ : C, 58.60; H, 6.88; N, 10.25 . Found: C, 58.39; H, 6.84; N, 10.26. MS $m / z: 409,411\left(\mathrm{M}^{+}, 3: 1\right)$. IR $v$ $(\mathrm{KBr}) \mathrm{cm}^{-1}: 1744,1646 .{ }^{1} \mathrm{H}-\mathrm{NMR}\left(\mathrm{CDCl}_{3}\right): 1.00-1.65(5 \mathrm{H}, \mathrm{m}), 1.27(3 \mathrm{H}$, $\mathrm{t}, J=7.5 \mathrm{~Hz}), 1.75-2.15(3 \mathrm{H}, \mathrm{m}), 2.35-2.65(2 \mathrm{H}, \mathrm{m}), 3.05-3.30(2 \mathrm{H}, \mathrm{m})$, $3.47(2 \mathrm{H}, \mathrm{s}), 3.89(3 \mathrm{H}, \mathrm{s}), 4.16(2 \mathrm{H}, \mathrm{q}, J=7.5 \mathrm{~Hz}), 4.30-4.55(1 \mathrm{H}, \mathrm{m}), 6.30$ $(1 \mathrm{H}, \mathrm{s}), 7.40-7.60(1 \mathrm{H}, \mathrm{m}), 8.10(1 \mathrm{H}, \mathrm{s})$.

Compounds $31 \mathbf{b}, \mathbf{c}$ were prepared in a manner similar to that described above and physicochemical data were summarized in Table 2 .

endo-3-[(4-Amino-5-chloro-2-methoxybenzoyl)amino]-9-azabicyclo[3.3.1]nonane-9-acetic Acid (32a) A mixture of 31a $(8.00 \mathrm{~g}$, $19.5 \mathrm{mmol})$ and $2 \mathrm{~N}$ aqueous $\mathrm{NaOH}$ solution $(19.5 \mathrm{ml}, 39.0 \mathrm{mmol})$ in $\mathrm{MeOH}$ $(80 \mathrm{ml})$ was refluxed for $1 \mathrm{~h}$. The reaction mixture was concentrated and the resulting residue was dissolved in a small amount of water. The solution was adjusted to $\mathrm{pH} 1$ with $10 \% \mathrm{HCl}$. The resulting precipitate was collected by filtration, washed with water and iso- $\mathrm{Pr}_{2} \mathrm{O}$, and recrystallized from a mixture of $\mathrm{MeOH}$ and iso- $\mathrm{Pr}_{2} \mathrm{O}$ to afford the hydrochloride $(5.75 \mathrm{~g}, 68 \%)$ of 32a as a colorless crystalline powder, mp $189-194^{\circ} \mathrm{C}$ (dec.). Anal. Calcd for $\mathrm{C}_{18} \mathrm{H}_{24} \mathrm{ClN}_{3} \mathrm{O}_{4} \cdot \mathrm{HCl} \cdot \mathrm{H}_{2} \mathrm{O}: \mathrm{C}, 49.55 ; \mathrm{H}, 6.23 ; \mathrm{N}, 9.63$. Found: $\mathrm{C}, 49.38 ; \mathrm{H}$, $5.99 ; \mathrm{N}, 9.49$. IR $v(\mathrm{KBr}) \mathrm{cm}^{-1}: 1732,1626 .{ }^{1} \mathrm{H}-\mathrm{NMR}$ (DMSO- $\left.d_{6}\right): 1.40-$ $1.65(3 \mathrm{H}, \mathrm{m}), 1.70-1.90(2 \mathrm{H}, \mathrm{m}), 1.95-2.30(3 \mathrm{H}, \mathrm{m}), 2.35-2.60(2 \mathrm{H}, \mathrm{m})$, $3.75-3.90(2 \mathrm{H}, \mathrm{m}), 3.84(3 \mathrm{H}, \mathrm{s}), 4.17(2 \mathrm{H}, \mathrm{s}), 4.35-4.55(1 \mathrm{H}, \mathrm{m}), 6.53$ $(1 \mathrm{H}, \mathrm{s}), 7.65(1 \mathrm{H}, \mathrm{s}), 7.55-7.85(1 \mathrm{H}, \mathrm{m})$.

Compounds 32b,c were prepared in a manner similar to that described above and their physicochemical data were summarized in Table 2 .

Method C. Methyl endo-3-[(4-Acetylamino-5-chloro-2-methoxybenzoyl)amino]-8-azabicyclo[3.2.1]octane-8-carboxylate (34) A mixture of $\left.3^{7}\right)^{7}(40.0 \mathrm{~g}, 0.109 \mathrm{mmol}), \mathrm{K}_{2} \mathrm{CO}_{3}(16.0 \mathrm{~g}, 0.116 \mathrm{~mol})$ and $\mathrm{ClCO}_{2} \mathrm{Me}$ $(80.0 \mathrm{ml}, 1.04 \mathrm{~mol})$ in chloroform $(400 \mathrm{ml})$ was refluxed for $19 \mathrm{~h}$. The resulting precipitate was filtered off and washed with $\mathrm{CH}_{2} \mathrm{Cl}_{2}$. The filtrate and washing $\mathrm{CH}_{2} \mathrm{Cl}_{2}$ were combined and evaporated, and the residue was washed successively with AcOEt and $\mathrm{MeOH}$ to give $17.5 \mathrm{~g} \mathrm{(39 \% )} \mathrm{of} \mathbf{3 4}$ as a colorless crystal, which was recrystallized from a mixture of $\mathrm{MeOH}$ and $\mathrm{CH}_{2} \mathrm{Cl}_{2}$ to afford colorless crystalline powder, mp $250-252^{\circ} \mathrm{C}$. Anal. Calcd for $\mathrm{C}_{19} \mathrm{H}_{24} \mathrm{ClN}_{3} \mathrm{O}_{5} \cdot 1 / 2 \mathrm{H}_{2} \mathrm{O}: \mathrm{C}, 54.48 ; \mathrm{H}, 6.02 ; \mathrm{N}, 10.03$. Found: $\mathrm{C}, 54.17 ; \mathrm{H}$, 5.77; N, 9.79. MS $m / z: 409,411\left(\mathrm{M}^{+}, 3: 1\right)$. IR $v$ (liq) $\mathrm{cm}^{-1}: 1704,1682$, 1652. ${ }^{1} \mathrm{H}-\mathrm{NMR}$ (DMSO- $\left.d_{6}\right): 1.70-1.85(2 \mathrm{H}, \mathrm{m}), 1.90-2.15(6 \mathrm{H}, \mathrm{m}), 2.15$ $(3 \mathrm{H}, \mathrm{s}), 3.61(3 \mathrm{H}, \mathrm{s}), 3.90(3 \mathrm{H}, \mathrm{s}), 4.05-4.25(3 \mathrm{H}, \mathrm{m}), 7.80(1 \mathrm{H}, \mathrm{s}), 7.81$ $(1 \mathrm{H}, \mathrm{s}), 8.25-8.40(1 \mathrm{H}, \mathrm{m}), 9.45(1 \mathrm{H}, \mathrm{br} \mathrm{s})$.

endo-4-Acetylamino- $N$-(8-azabicyclo[3.2.1]oct-3-yl)-5-chloro-2methoxybenzamide (35) A mixture of $34(16.3 \mathrm{~g}, 39.8 \mathrm{mmol})$ and trimethylsilyl iodide $(22.0 \mathrm{ml}, 155 \mathrm{mmol})$ in $\mathrm{CH}_{2} \mathrm{Cl}_{2}(400 \mathrm{ml})$ was stirred at room temperature for $6 \mathrm{~h}$. Sodium hydrogensulfite solution was added to the reaction mixture. The mixture was stirred at room temperature for $15 \mathrm{~min}$ and adjusted to $\mathrm{pH} 2$ with $10 \% \mathrm{HCl}$. The aqueous layer was basified with $\mathrm{K}_{2} \mathrm{CO}_{3}$ and extracted with $\mathrm{CH}_{2} \mathrm{Cl}_{2}$. The extract was washed with water, dried and evaporated to give a yellow brown oil, which was purified by column chromatography [alumina, $\mathrm{CH}_{2} \mathrm{Cl}_{2}-\mathrm{MeOH}(50: 1)$ ] to afford $8.41 \mathrm{~g}(60 \%)$ of 
35 as a pale yellow viscous oil. MS $m / z: 351,353\left(\mathrm{M}^{+}, 3: 1\right)$. IR $v(\mathrm{KBr})$ $\mathrm{cm}^{-1}: 1694,1644 .{ }^{1} \mathrm{H}-\mathrm{NMR}\left(\mathrm{CDCl}_{3}\right): 1.65-2.30(9 \mathrm{H}, \mathrm{m}), 2.28(3 \mathrm{H}, \mathrm{s})$, $3.60-3.75(2 \mathrm{H}, \mathrm{m}), 4.02(3 \mathrm{H}, \mathrm{s}), 4.30-4.45(1 \mathrm{H}, \mathrm{m}), 7.82(1 \mathrm{H}, \mathrm{br} \mathrm{s}), 8.21$ $(1 \mathrm{H}, \mathrm{s}), 8.34(1 \mathrm{H}, \mathrm{s}), 8.40-8.50(1 \mathrm{H}, \mathrm{m})$.

Ethyl endo-3-[(4-Acetylamino-5-chloro-2-methoxybenzoyl)amino]-8azabicyclo[3.2.1] octane-8-acetate (36) A mixture of $\mathbf{3 5}(8.00 \mathrm{~g}, 22.7$ $\mathrm{mmol})$, ethyl bromoacetate $(4.18 \mathrm{~g}, 25.0 \mathrm{mmol})$ and $\mathrm{K}_{2} \mathrm{CO}_{3}(3.46 \mathrm{~g}, 25.0$ $\mathrm{mmol})$ in DMF $(50 \mathrm{ml})$ was stirred at $60^{\circ} \mathrm{C}$ for $2 \mathrm{~h}$. After the addition of water, the reaction mixture was extracted with AcOEt. The extract was washed with water, dried and evaporated. The resulting residue was washed with iso- $\mathrm{Pr}_{2} \mathrm{O}$ to give $5.20 \mathrm{~g} \mathrm{(52 \% )}$ of $\mathbf{3 6}$ as a colorless crystal, which was recrystallized from EtOH to afford colorless prisms, mp $144-145^{\circ} \mathrm{C}$. Anal. Calcd for $\mathrm{C}_{21} \mathrm{H}_{28} \mathrm{ClN}_{3} \mathrm{O}_{5}$ : C, 57.60; H, 6.44; N, 9.60. Found: C, 57.45; H, 6.32; N, 9.49. MS $m / z: 437,439\left(\mathrm{M}^{+}, 3: 1\right)$. IR $v(\mathrm{KBr}) \mathrm{cm}^{-1}: 1738,1704$, 1640. ${ }^{1} \mathrm{H}-\mathrm{NMR}\left(\mathrm{CDCl}_{3}\right): 1.29(3 \mathrm{H}, \mathrm{t}, J=7 \mathrm{~Hz}), 1.65-2.45(9 \mathrm{H}, \mathrm{m}), 2.28$ $(3 \mathrm{H}, \mathrm{s}), 3.26(2 \mathrm{H}, \mathrm{s}), 3.30-3.50(2 \mathrm{H}, \mathrm{m}), 4.02(3 \mathrm{H}, \mathrm{s}), 4.21(2 \mathrm{H}, \mathrm{q}$, $J=7 \mathrm{~Hz}), 4.25-4.40(1 \mathrm{H}, \mathrm{m}), 7.80(1 \mathrm{H}, \mathrm{brs}), 8.21(1 \mathrm{H}, \mathrm{s}), 8.34(1 \mathrm{H}, \mathrm{s})$, $8.35-8.50(1 \mathrm{H}, \mathrm{m})$

Ethyl endo-3-[(4-Amino-5-chloro-2-methoxybenzoyl)amino]-8-azabicyclo[3.2.1]octane-8-acetate (37) A mixture of $36(4.60 \mathrm{~g}, 10.5 \mathrm{mmol})$ and $10 \%$ ethanolic hydrochloride $(30 \mathrm{ml})$ in $\mathrm{EtOH}(10 \mathrm{ml})$ was refluxed for $1 \mathrm{~h}$. The reaction mixture was evaporated and water was added to the resulting residue. The aqueous layer was washed with AcOEt and then adjusted to pH 9 with $10 \%$ aqueous $\mathrm{K}_{2} \mathrm{CO}_{3}$. The resulting crystals were collected by filtration and washed with water and iso- $\mathrm{Pr}_{2} \mathrm{O}$ to give $4.09 \mathrm{~g}(98 \%)$ of 37 as a pale yellow crystal, which was recrystallized from $\mathrm{EtOH}$ to afford colorless crystals, mp 187- $188^{\circ} \mathrm{C}$. Anal. Calcd for $\mathrm{C}_{19} \mathrm{H}_{26} \mathrm{ClN}_{3} \mathrm{O}_{4}$ : C, 57.65; H, 6.62; $\mathrm{N}, 10.61$. Found: C, 57.57; H, 6.52; N, 10.42. MS m/z: 395, $397\left(\mathrm{M}^{+}, 3: 1\right)$. IR $v(\mathrm{KBr}) \mathrm{cm}^{-1}: 1748,1640 .{ }^{1} \mathrm{H}-\mathrm{NMR}\left(\mathrm{CDCl}_{3}\right): 1.28(3 \mathrm{H}, \mathrm{t}, J=7 \mathrm{~Hz})$, $1.60-2.50(8 \mathrm{H}, \mathrm{m}), 3.26(2 \mathrm{H}, \mathrm{s}), 3.25-3.50(2 \mathrm{H}, \mathrm{m}), 3.93(3 \mathrm{H}, \mathrm{s}), 4.20$ $(2 \mathrm{H}, \mathrm{q}, J=7 \mathrm{~Hz}), 4.20-4.40(1 \mathrm{H}, \mathrm{m}), 4.41(2 \mathrm{H}, \mathrm{brs}), 6.31(1 \mathrm{H}, \mathrm{s}), 8.10$ $(1 \mathrm{H}, \mathrm{s}), 8.20-8.35(1 \mathrm{H}, \mathrm{m})$.

endo-3-[(4-Amino-5-chloro-2-methoxybenzoyl)amino]-8-azabicyclo[3.2.1]octane-8-acetic Acid (38) A mixture of $37(3.60 \mathrm{~g}, 9.09 \mathrm{mmol})$ and $2 \mathrm{~N}$ aqueous $\mathrm{NaOH}$ solution $(9.1 \mathrm{ml})$ in $\mathrm{MeOH}(36 \mathrm{ml})$ was refluxed for $1 \mathrm{~h}$. The reaction mixture was concentrated and the resulting residue was dissolved in a small amount of water. The solution was adjusted to $\mathrm{pH} 1$ with $10 \% \mathrm{HCl}$. The resulting precipitate was collected by filtration and washed with water to give crude crystals, which were recrystallized from water to afford the hydrochloride $(3.19 \mathrm{~g}, 81 \%)$ of $\mathbf{3 8}$ as a pale yellow crystal, mp $254-256^{\circ} \mathrm{C}$ (dec.). Anal. Calcd for $\mathrm{C}_{17} \mathrm{H}_{22} \mathrm{ClN}_{3} \mathrm{O}_{4} \cdot \mathrm{HCl} \cdot 3 / 2 \mathrm{H}_{2} \mathrm{O}: \mathrm{C}$, 47.34; H, 6.08; N, 9.74. Found: C, 47.36; H, 5.96; N, 9.79. MS m/z: 367, $369\left(\mathrm{M}^{+}, 3: 1\right)$. IR $v(\mathrm{KBr}) \mathrm{cm}^{-1}: 1736,1628 .{ }^{1} \mathrm{H}-\mathrm{NMR}\left(\mathrm{DMSO}-d_{6}\right): 1.95-$ $2.60(8 \mathrm{H}, \mathrm{m}), 3.85(3 \mathrm{H}, \mathrm{s}), 3.95-4.15(1 \mathrm{H}, \mathrm{m}), 4.01(2 \mathrm{H}, \mathrm{s}), 5.90(2 \mathrm{H}, \mathrm{br})$, $6.56(1 \mathrm{H}, \mathrm{s}), 7.65(1 \mathrm{H}, \mathrm{s}), 8.05-8.20(1 \mathrm{H}, \mathrm{m})$.

Method D. endo- $N$-(9-Benzyl-9-azabicyclo[3.3.1]non-3-yl)-1-methyl1H-indazole-3-carboxamide (40d) A mixture of endo-3-amino-9-benzyl9-azabicyclo[3.3.1]nonane $(13.8 \mathrm{~g}, 59.9 \mathrm{mmol}), \mathrm{Et}_{3} \mathrm{~N}(6.60 \mathrm{~g}, 65.2 \mathrm{mmol})$ and 1-methyl-1H-indazole-3-carbonyl chloride 39d $(10.2 \mathrm{~g}, 52.2 \mathrm{mmol})$ in $\mathrm{CH}_{2} \mathrm{Cl}_{2}(150 \mathrm{ml})$ was stirred at room temperature for $2 \mathrm{~h}$. The reaction mixture was washed with water, dried and evaporated. The resulting residue was purified by column chromatography $\left(\mathrm{SiO}_{2}, \mathrm{CHCl}_{3}\right)$ and crystallized from iso- $\mathrm{Pr}_{2} \mathrm{O}$ to give $14.75 \mathrm{~g}(73 \%)$ of $\mathbf{4 0 d}$ as a colorless crystal, which was recrystallized from $\mathrm{MeOH}$ to afford colorless needles, mp $161-162^{\circ} \mathrm{C}$. Anal. Calcd for $\mathrm{C}_{24} \mathrm{H}_{28} \mathrm{~N}_{4} \mathrm{O}: \mathrm{C}, 74.20 ; \mathrm{H}, 7.26 ; \mathrm{N}, 14.42$. Found: C, 74.15; H, 7.32; $\mathrm{N}, 14.41$. MS $m / z: 388\left(\mathrm{M}^{+}\right)$. IR $v(\mathrm{KBr}) \mathrm{cm}^{-1}: 1672 .{ }^{1} \mathrm{H}-\mathrm{NMR}\left(\mathrm{CDCl}_{3}\right)$ : $0.75-2.25(8 \mathrm{H}, \mathrm{m}), 2.25-2.75(2 \mathrm{H}, \mathrm{m}), 2.90-3.35(2 \mathrm{H}, \mathrm{m}), 3.87(2 \mathrm{H}, \mathrm{s})$, $4.09(3 \mathrm{H}, \mathrm{s}), 4.50-4.95(1 \mathrm{H}, \mathrm{m}), 6.70-6.95(1 \mathrm{H}, \mathrm{m}), 7.05-7.65(8 \mathrm{H}, \mathrm{m})$, $8.35-8.55(1 \mathrm{H}, \mathrm{m})$.

Compounds 40e, $\mathbf{f}$ were prepared in a manner similar to that described above. 40e: $\mathrm{mp} 212-214^{\circ} \mathrm{C}\left(\mathrm{CH}_{2} \mathrm{Cl}_{2}-\mathrm{MeOH}\right)$. Anal. Calcd for $\mathrm{C}_{24} \mathrm{H}_{27} \mathrm{~N}_{3} \mathrm{O}$ : C, 77.18; H, 7.29; N, 11.25. Found: C, 77.08; H, 7.34; N, 11.24. MS $m / z$ : $373\left(\mathrm{M}^{+}\right)$. IR $v(\mathrm{KBr}) \mathrm{cm}^{-1}: 1620 .{ }^{1} \mathrm{H}-\mathrm{NMR}$ (DMSO- $\left.d_{6}\right): 0.70-2.75(10 \mathrm{H}$, $\mathrm{m}), 2.85-3.30(2 \mathrm{H}, \mathrm{m}), 3.83(2 \mathrm{H}, \mathrm{s}), 4.05-4.85(1 \mathrm{H}, \mathrm{m}), 6.90-7.60(9 \mathrm{H}$, m), $7.99(1 \mathrm{H}, \mathrm{d}, J=3 \mathrm{~Hz}), 8.10-8.30(1 \mathrm{H}, \mathrm{m}), 11.38(1 \mathrm{H}, \mathrm{brs}) .40 \mathrm{f}: \mathrm{mp}$ 210-211 ${ }^{\circ} \mathrm{C}$ (EtOH). Anal. Calcd for $\mathrm{C}_{25} \mathrm{H}_{29} \mathrm{~N}_{3} \mathrm{O}: \mathrm{C}, 77.49 ; \mathrm{H}, 7.54 ; \mathrm{N}$, 10.84. Found: $\mathrm{C}, 77.45 ; \mathrm{H}, 7.57 ; \mathrm{N}, 11.10$. MS $m / z$ : $387\left(\mathrm{M}^{+}\right)$. IR $v(\mathrm{KBr})$ $\mathrm{cm}^{-1}: 1614 .{ }^{1} \mathrm{H}-\mathrm{NMR}\left(\mathrm{CDCl}_{3}\right): 0.80-2.20(8 \mathrm{H}, \mathrm{m}), 2.30-2.80(2 \mathrm{H}, \mathrm{m})$, $3.00-3.30(2 \mathrm{H}, \mathrm{m}), 3.76(3 \mathrm{H}, \mathrm{s}), 3.86(2 \mathrm{H}, \mathrm{s}), 4.25-5.10(1 \mathrm{H}, \mathrm{m}), 5.70-$ $5.80(1 \mathrm{H}, \mathrm{m}), 7.10-7.50(8 \mathrm{H}, \mathrm{m}), 7.63(1 \mathrm{H}, \mathrm{s}), 7.80-8.15(1 \mathrm{H}, \mathrm{m})$.

endo- $N$-(9-Azabicyclo[3.3.1 ]non-3-yl)-1-methyl-1H-indazole-3-carboxamide (41d) A mixture of 40d $(12.9 \mathrm{~g}, 3.32 \mathrm{mmol})$, Pearlman's catalyst $(2.0 \mathrm{~g})$ and acetic acid $(25 \mathrm{ml})$ in $\mathrm{MeOH}(225 \mathrm{ml})$ was stirred at room temperature and atmospheric pressure of $\mathrm{H}_{2}$ for $3 \mathrm{~h}$. The catalyst was removed by filtration and the filtrate was evaporated. The resulting residue was dissolved in $10 \% \mathrm{HCl}$ and the insoluble substance was removed by filtration. The filtrate was basified with $\mathrm{K}_{2} \mathrm{CO}_{3}$ and the precipitate was collected by filtration, washed with water and dried to give $9.90 \mathrm{~g}(100 \%)$ of $\mathbf{4 1 d}$ as a colorless amorphous solid, which was converted to the hydrochloride in the usual manner. The hydrochloride was recrystallized from $\mathrm{EtOH}$ to afford colorless needles, $\mathrm{mp}>300^{\circ} \mathrm{C}$. Anal. Calcd for $\mathrm{C}_{17} \mathrm{H}_{22} \mathrm{~N}_{4} \mathrm{O} \cdot \mathrm{HCl}$ : C, 60.98; H, 6.92; N, 16.73. Found: C, 60.77; H, 7.01; N, 16.55. MS m/z: $298\left(\mathrm{M}^{+}\right)$. IR $v$ $(\mathrm{KBr}) \mathrm{cm}^{-1}: 1640 .{ }^{1} \mathrm{H}-\mathrm{NMR}$ (DMSO- $\left.d_{6}\right): 1.25-2.65(10 \mathrm{H}, \mathrm{m}), 3.35(1 \mathrm{H}$, br s), 3.55-3.95 $(2 \mathrm{H}, \mathrm{m}), 4.13(3 \mathrm{H}, \mathrm{s}), 4.25-4.80(1 \mathrm{H}, \mathrm{m}), 7.15-7.80$ $(3 \mathrm{H}, \mathrm{m}), 8.05-8.35(1 \mathrm{H}, \mathrm{m}), 8.40-9.40(1 \mathrm{H}, \mathrm{m})$.

Compounds 41e, $\mathbf{f}$ were prepared in a manner similar to that described above. 41e: $\mathrm{mp} 232-236^{\circ} \mathrm{C}$ (dec., aqueous $\mathrm{EtOH}$ ). Anal. Calcd for $\mathrm{C}_{17} \mathrm{H}_{21} \mathrm{~N}_{3} \mathrm{O} \cdot \mathrm{H}_{2} \mathrm{O}: \mathrm{C}, 67.75 ; \mathrm{H}, 7.69 ; \mathrm{N}, 13.94$. Found: $\mathrm{C}, 67.85 ; \mathrm{H}, 7.76 ; \mathrm{N}$, 13.86. MS $m / z: 283\left(\mathrm{M}^{+}\right)$. IR $v(\mathrm{KBr}) \mathrm{cm}^{-1}: 1606 .{ }^{1} \mathrm{H}-\mathrm{NMR}$ (DMSO- $\left.d_{6}\right)$ : $0.90-2.35(10 \mathrm{H}, \mathrm{m}), 2.95-3.55(2 \mathrm{H}, \mathrm{m}), 3.80-4.50(1 \mathrm{H}, \mathrm{m}), 6.90-7.55$ $(4 \mathrm{H}, \mathrm{m}), 7.99(1 \mathrm{H}, \mathrm{s}), 8.00-8.25(1 \mathrm{H}, \mathrm{m}), 11.39(1 \mathrm{H}, \mathrm{br}) . \mathbf{4 1 f}: \mathrm{mp} 218-$ $219^{\circ} \mathrm{C}$ (EtOH). Anal. Calcd for $\mathrm{C}_{18} \mathrm{H}_{23} \mathrm{~N}_{3} \mathrm{O}: \mathrm{C}, 72.70 ; \mathrm{H}, 7.80 ; \mathrm{N}, 14.13$. Found: C, 72.54; H, 7.84; N, 13.96. MS $m / z: 297\left(\mathrm{M}^{+}\right)$. IR $v(\mathrm{KBr}) \mathrm{cm}^{-1}$ : 1614. ${ }^{1} \mathrm{H}-\mathrm{NMR}\left(\mathrm{CDCl}_{3}\right): 1.00-2.10(8 \mathrm{H}, \mathrm{m}), 1.90(1 \mathrm{H}, \mathrm{s}), 2.10-2.60(2 \mathrm{H}$, $\mathrm{m}), 3.20-3.55(2 \mathrm{H}, \mathrm{m}), 3.80(1 \mathrm{H}, \mathrm{s}), 4.00-4.60(1 \mathrm{H}, \mathrm{m}), 5.60-5.95(1 \mathrm{H}$, m), $7.10-7.50(3 \mathrm{H}, \mathrm{m}), 7.67(1 \mathrm{H}, \mathrm{s}), 7.80-8.05(1 \mathrm{H}, \mathrm{m})$.

Ethyl endo-3-[[(1-Methyl-1H-indazol-3-yl)carbonyl]amino]-9-azabicyclo[3.3.1]nonane-9-acetate (42d) A mixture of 41d $(2.50 \mathrm{~g}, 8.38 \mathrm{mmol})$, ethyl bromoacetate $(1.54 \mathrm{~g}, 9.22 \mathrm{mmol})$ and $\mathrm{K}_{2} \mathrm{CO}_{3}(1.16 \mathrm{~g}, 8.39 \mathrm{mmol})$ in DMF $(20 \mathrm{ml})$ was stirred at $70^{\circ} \mathrm{C}$ for $4.5 \mathrm{~h}$. After the addition of water, the reaction mixture was extracted with $\mathrm{Et}_{2} \mathrm{O}$. The extract was washed with water, dried and evaporated. The residue was purified by column chromatography $\left[\mathrm{SiO}_{2}, \mathrm{CH}_{2} \mathrm{Cl}_{2}\right]$ to afford $2.69 \mathrm{~g}(84 \%)$ of $\mathbf{4 2 d}$ as a pale yellow viscous oil. High resolution MS m/z: Calcd for $\mathrm{C}_{21} \mathrm{H}_{28} \mathrm{~N}_{4} \mathrm{O}_{3}: 384.2161$. Found: 384.2173. MS $m / z$ : $384\left(\mathrm{M}^{+}\right)$. IR $v(\mathrm{KBr}) \mathrm{cm}^{-1}: 1748,1662 .{ }^{1} \mathrm{H}-\mathrm{NMR}$ $\left(\mathrm{CDCl}_{3}\right): 0.90-2.25(8 \mathrm{H}, \mathrm{m}), 1.28(3 \mathrm{H}, \mathrm{t}, J=7.5 \mathrm{~Hz}), 2.25-2.80(2 \mathrm{H}, \mathrm{m})$, $3.05-3.45(2 \mathrm{H}, \mathrm{m}), 3.49(2 \mathrm{H}, \mathrm{s}), 4.08(3 \mathrm{H}, \mathrm{s}), 4.17(2 \mathrm{H}, \mathrm{q}, J=7.5 \mathrm{~Hz})$, $4.20-4.80(1 \mathrm{H}, \mathrm{m}), 6.65-6.95(1 \mathrm{H}, \mathrm{m}), 7.10-7.60(3 \mathrm{H}, \mathrm{m}), 8.20-8.50$ $(1 \mathrm{H}, \mathrm{m})$.

Compounds 42e, $\mathbf{f}$ were prepared in a manner similar to that described above and their physicochemical data were summarized in Table 3 .

endo-3-[[(1-Methyl-1 $H$-indazol-3-yl)carbonyl]amino]-9-azabicyclo[3.3.1]nonane-9-acetic Acid (43d) A mixture of 42d (2.00 g, $5.20 \mathrm{mmol})$ and $2 \mathrm{~N}$ aqueous $\mathrm{NaOH}$ solution $(5.2 \mathrm{ml})$ in $\mathrm{MeOH}(20 \mathrm{ml})$ was refluxed for $1 \mathrm{~h}$. The reaction mixture was evaporated and the resulting residue was dissolved in a small amount of water. The solution was adjusted to $\mathrm{pH} 2$ with $10 \%$ aqueous $\mathrm{HCl}$. The resulting precipitate was collected by filtration to afford $1.50 \mathrm{~g}(67 \%)$ of $\mathbf{4 3 d}$ as a colorless amorphass solid. Anal. Calcd for $\mathrm{C}_{19} \mathrm{H}_{24} \mathrm{~N}_{4} \mathrm{O}_{3} \cdot \mathrm{HCl} \cdot 2 \mathrm{H}_{2} \mathrm{O}: \mathrm{C}, 53.21 ; \mathrm{H}, 6.81 ; \mathrm{N}, 13.06$. Found: $\mathrm{C}, 53.34 ; \mathrm{H}$, 6.66; N, 13.04. MS $m / z: 357\left(\mathrm{M}^{+}+1\right)$. IR $v(\mathrm{KBr}) \mathrm{cm}^{-1}: 1744,1652 .{ }^{1} \mathrm{H}-$ NMR (DMSO- $\left.d_{6}\right): 1.25-2.70(10 \mathrm{H}, \mathrm{m}), 3.70-4.05(2 \mathrm{H}, \mathrm{m}), 4.14(3 \mathrm{H}, \mathrm{s})$, $4.18(2 \mathrm{H}, \mathrm{s}), 4.35-5.05(1 \mathrm{H}, \mathrm{m}), 7.10-7.85(3 \mathrm{H}, \mathrm{m}), 8.00-8.50(2 \mathrm{H}, \mathrm{m})$.

Compounds $43 \mathrm{e}, \mathbf{f}$ were prepared in a manner similar to that described above and their physicochemical data was summarized in Table 3.

Method E. Methyl 4-[(4-Amino-5-chloro-2-methoxybenzoyl)amino]1-piperidineacetate (44) To a suspension of $19(5.00 \mathrm{~g}, 14.6 \mathrm{mmol})$ in $\mathrm{MeOH}(75 \mathrm{ml})$ was added concentrated sulfuric acid $(1.80 \mathrm{~g})$. The mixture was refluxed for $16 \mathrm{~h}$. After cooling, the solvent was evaporated to give the residue, which was basified $(\mathrm{pH}=9)$ with aqueous $\mathrm{K}_{2} \mathrm{CO}_{3}$ and extracted with $\mathrm{CH}_{2} \mathrm{Cl}_{2}$. The extract was washed with saturated aqueous $\mathrm{NaCl}$, dried and evaporated to afford $3.82 \mathrm{~g} \mathrm{(74 \% )}$ of $\mathbf{4 4}$ as pale brown residue, which was recrystallized from $\mathrm{MeOH}$ to afford $2.95 \mathrm{~g}$ of pale brown prisms, mp 196 $197^{\circ} \mathrm{C}$. Anal. Calcd for $\mathrm{C}_{16} \mathrm{H}_{22} \mathrm{ClN}_{3} \mathrm{O}_{4}$ : C, $54.01 ; \mathrm{H}, 6.23 ; \mathrm{N}, 11.81$. Found: C, 53.80; H, 6.14; N, 11.83. MS m/z: 355, $357\left(3: 1, \mathrm{M}^{+}\right)$. IR $v(\mathrm{KBr}) \mathrm{cm}^{-1}$ : $3400,3320,3216,1756 .{ }^{1} \mathrm{H}-\mathrm{NMR}$ (DMSO- $\left.d_{6}\right): 1.45-1.55(2 \mathrm{H}, \mathrm{m}), 1.75-$ $1.85(2 \mathrm{H}, \mathrm{m}), 2.30-2.35(2 \mathrm{H}, \mathrm{m}), 2.70-2.80(2 \mathrm{H}, \mathrm{m}), 3.23(2 \mathrm{H}, \mathrm{s}), 3.62$ $(3 \mathrm{H}, \mathrm{s}), 3.70-3.85(1 \mathrm{H}, \mathrm{m}), 3.85(3 \mathrm{H}, \mathrm{s}), 5.80(2 \mathrm{H}, \mathrm{br} \mathrm{s}), 6.50(1 \mathrm{H}, \mathrm{s}), 7.67$ $(1 \mathrm{H}, \mathrm{s}), 7.68(1 \mathrm{H}, \mathrm{d}, J=7.5 \mathrm{~Hz})$.

n-Propyl 4-[(4-Amino-5-chloro-2-methoxybenzoyl)amino]-1-piperidineacetate (45) A solution of $n$-propyl bromide $(1.78 \mathrm{~g}, 14.5 \mathrm{mmol})$ in DMF $(15 \mathrm{ml})$ was added to a suspension of $19(4.50 \mathrm{~g}, 13.2 \mathrm{mmol})$ and $\mathrm{K}_{2} \mathrm{CO}_{3}$ $(2.00 \mathrm{~g}, 14.5 \mathrm{~mol})$ in DMF $(135 \mathrm{ml})$ at $60^{\circ} \mathrm{C}$ over $1 \mathrm{~h}$. The mixture was stirred at $60^{\circ} \mathrm{C}$ for $2 \mathrm{~h}$. After cooling, the reaction mixture was added to water and extracted with toluene. The extract was washed with saturated aqueous $\mathrm{NaCl}$, dried and evaporated to afford colorless residue. The residue was washed with $n$-heptane to afford $3.94 \mathrm{~g}(78 \%)$ of the crude 45 , which was converted to the mesylate in the usual manner. The mesylate of $\mathbf{4 5}$ was recrystallized from iso-PrOH to give a colorless crystal, $\mathrm{mp} 209-210^{\circ} \mathrm{C}$. 
Anal. Calcd for $\mathrm{C}_{18} \mathrm{H}_{26} \mathrm{ClN}_{3} \mathrm{O}_{4} \cdot \mathrm{CH}_{4} \mathrm{O}_{3} \mathrm{~S}: \mathrm{C}, 47.54 ; \mathrm{H}, 6.30 ; \mathrm{N}, 8.75$. Found: $\mathrm{C}, 47.47 ; \mathrm{H}, 6.41 ; \mathrm{N}, 8.69$. MS $m / z: 383,385\left(3: 1, \mathrm{M}^{+}\right)$. IR $v(\mathrm{KBr}) \mathrm{cm}^{-1}$ : 3408, 3324, 3216, 1754. ${ }^{1} \mathrm{H}-\mathrm{NMR}$ (DMSO- $d_{6}$ ): 0.93 (3H, t, $\left.J=7 \mathrm{~Hz}\right), 1.66$ $(2 \mathrm{H}$, sextet, $J=7 \mathrm{~Hz}), 1.70-2.00(2 \mathrm{H}, \mathrm{m}), 2.00-2.10(2 \mathrm{H}, \mathrm{m}), 2.33(3 \mathrm{H}, \mathrm{s})$, $3.10-3.40(2 \mathrm{H}, \mathrm{m}), 3.40-3.70(2 \mathrm{H}, \mathrm{m}), 3.84(3 \mathrm{H}, \mathrm{s}), 3.90-4.10(1 \mathrm{H}, \mathrm{m})$, $4.17(2 \mathrm{H}, \mathrm{br} \mathrm{s}), 4.22(2 \mathrm{H}, \mathrm{br} \mathrm{s}), 5.82(2 \mathrm{H}, \mathrm{brs}), 6.52(1 \mathrm{H}, \mathrm{s}), 7.63(1 \mathrm{H}, \mathrm{s})$, $7.74(1 \mathrm{H}, \mathrm{brs}), 9.92(1 \mathrm{H}, \mathrm{brs})$

Compounds 46-60 were prepared in a manner similar to that described above and their physicochemical data were summarized in Table 4 .

\section{Pharmacology}

Gastrointestinal Contractile Activity in Dogs The gastrointestinal motility was measured, according to the method of Z. Itoh et al., in dogs of both sexes, weighing 7.9 to $12.0 \mathrm{~kg}$. Under general anesthesia, a strain-gauge force transducer was chronically sutured on the ascending colon $10 \mathrm{~cm}$ distal to the cecum in a direction to measure circular muscle contractions. A sailastic cannula for intravenous (i.v.) or intra-duodenal (i.d.) administration of the tested compound was placed into the superior vena cava or duodenum. The administration of the tested compounds to the dogs was performed more than 2 weeks after the surgery. The tested compounds were solved in saline, including $1 \%$ lactic acid, and were intravenously or intra-duodenally administered to the animals more than $2 \mathrm{~h}$ after feeding. Gastric motility was expressed as a symbol based on a motor index, representing the area surrounded by the construction wave and the base line during a $20 \mathrm{~min}$ period. Colonic motility was expressed as a ratio of the number of dogs, showing giant contractions in the ascending colon during $40 \mathrm{~min}$ after the administration, versus the number of tested dogs.

Dopamine $\mathbf{D}_{2}$ Binding Assay The test compounds at the concentration of $1-100 \mu \mathrm{M}$ were tested in binding assays using rat brain synaptic membranes for competition with $\left[{ }^{3} \mathrm{H}\right]$ Spiperon in the rat striatum at their respective binding sites. Each assay was started by an addition of tissue preparation and terminated by rapid filtration through a Whatman GF/B glass fiber filter under the reduced pressure. The filters were washed three times with $5 \mathrm{ml}$ of ice-cold buffer and transferred to scintillation vials that contained $7 \mathrm{ml}$ of scintillator, and the radioactivity in the filter was counted with a scintillation counter. $\mathrm{IC}_{50}$ values (the concentration causing 50 inhibition of ${ }^{3} \mathrm{H}$-labeled ligand specific binding) of the test compounds were calculated with the equation of Cheng and Prusoff.

5-HT 4 Agonist Activity The esophagus was removed from a male Wister rat, and two preparations, obtained from each animal, was used as a longitudinal preparation. The tissues were mounted in organ baths containing $10 \mathrm{ml}$ of Krebs-Henseleit solution. The bathing medium was maintained at $37^{\circ} \mathrm{C}, \mathrm{pH} 7.4$, and was equilibrated with a gas mixture consisting of $95 \% \mathrm{O}_{2}$ and $5 \% \mathrm{CO}_{2}$. An initial tension of $1.0 \mathrm{~g}$ was applied and the responses were recorded isometrically with a force-displacement transducer. All preparations were equilibrated for at least $60 \mathrm{~min}$ before the start of the experiments. Once the carbachol $\left(10^{-6} \mathrm{M}\right)$-induced contractions reached a steady state, drugs were added cumulatively, and relaxation was calculated as a percentage of the initial carbachol-induced force.

Emetic Action in Ferrets Male ferrets, weighing 0.9 to $1.3 \mathrm{~kg}$, and fasted for $16 \mathrm{~h}$, were used. The tested compounds were dissolved with $10 \%$ aqueous DMSO solution and were administered orally (p.o.). Then, the incidence of vomiting during the $2 \mathrm{~h}$ after the administration was observed.

Physicochemical Stability The tested compounds were dissolved in the pH6.8 buffer solution (Japanese Pharmacopoeia 2nd fluid), and the solution was heated at $37^{\circ} \mathrm{C}$ for $3 \mathrm{~h}$. The initial concentration of prodrug was $100 \mu \mathrm{g} / \mathrm{ml}$. The concentration of prodrug that remained was determined by
HPLC.

Metabolic Stability with Human Liver S9 The tested compounds were added to human liver S9 (HBI, $0.1 \mathrm{mg}$ protein $/ \mathrm{ml}$ ), pre-incubated at $37^{\circ} \mathrm{C}$, and the mixture was incubated at $37^{\circ} \mathrm{C}$ for $30 \mathrm{~min}$. The initial concentration of prodrug was $1 \mu \mathrm{mol} / 1$. The concentration of prodrug that remained was determined by HPLC.

Brain Distribution The tested compounds were administrated intravenously to CD-1(ICR) mice (CharlesRiver Japan, male, $10 \mathrm{mg} / \mathrm{kg}, n=4$ ). Blood and brain were taken $2 \mathrm{~min}$ after administration. The concentrations of plasma and brain were determined by HPLC or liquid chromatography/ mass spectrometory/mass spectrometory (LC/MS/MS). Brain distribution was estimated from the concentration ratio of each compound in brain to plasma.

Acknowledgments We are grateful to Dr. N. Kado, Research Division, Hokuriku Seiyaku Co., Ltd., for his encouragement and valuable comments through out this work. Thanks are also due to the staff of our analytical section for elemental analyses and spectral measurements.

\section{References}

1) a) Dumuis A., Sebben M., Bockaert J., Naunyn-Schmideberg's Arch. Pharmacol., 340, 403-410 (1989); b) Harrington R. A., Hamilton C. W., Brogden R. N., Linkewich J. A., Romankiewicz J. A., Heel R. C., Drugs, 25, 451— 494 (1983).

2) Sakaguchi J., Nishino H., Ogawa N., Iwanaga Y., Yasuda S., Kato H., Ito Y., Chem. Pharm. Bull., 40, 202-211 (1992).

3) Iwasaki N., Sakaguchi J., Ohashi T., Takahara E., Ogawa N., Yasuda S., Koshinaka E., Kato H., Ito Y., Sawanishi H., Chem. Pharm. Bull., 42, 2276-2284 (1994); Iwasaki N., Sakaguchi J., Ohashi T., Yamazaki M., Ogawa N., Yasuda S., Koshinaka E., Kato H., Ito Y., Sawanishi H., ibid., 42, 2285-2290 (1994).

4) Van Daele G. H. P., De Bruyn M. F. L., Sommen F. M., Janssen M., Van Nueten J. M., Schuurkes J. A. J., Niemegeers C. J. E., Leysen J. E., Drug Development Research, 8, 225-232 (1986).

5) Spickett R. G., Moragues J., Prieto J., Japan. Patent 50-129573 (1975).

6) Luwig Heumann \& Co GmbH, Japan. Patent 50-32144 (1975).

7) Hadley M. S., King F. D., Japan. Patent 55—92384 (1980).

8) Bermudez J., Fake C. S., Joiner G. F., Joiner K. A., King F. D., Miner W. D., Sanger G. J., J. Med. Chem., 33, $1924-1929$ (1990).

9) Donatch P., Engel G., Huegi B., Richardson B. P., Stadler P., Japan. Patent 59-67284 (1984).

10) Itoh Z., Jap. J. Smooth Muscle Res., 13, 33- 43 (1976).

11) Prieto J., Moragues J., Spickett R. G., Vega A., Colombo M., Salazar W., Roberts D. J., J. Pharm. Pharmac., 29, 147-152 (1977).

12) Gaster L. M., Joiner G. F., King F. D., Wyman P. A., Sutton J. M., Bingham S., Ellis E. S., Sanger G. J., Wardle K. A., J. Med. Chem., 38, $4760-4763$ (1995).

13) López-Rodríguez M. L., Morcillo M. J., Benhamú B., Rosado M. L., J. Comput.-Aided Mol. Des., 11, 589-599 (1997).

14) Fujitsu Limited, 1-9-3 Nakase, Mihama-ku, Chiba 261-8588, Japan, version 4.1.1

15) Flynn D. L., Zabrowski D. L., Becker D. P., Nosal R., Villamil C. I., Gullikson G. W., Moummi C., Yang D. C., J. Med. Chem., 35, 14861489 (1992). 